\title{
D-chiro-Inositol Ribophostin: A Highly Potent Agonist of D-myo- Inositol 1,4,5-Trisphosphate Receptors: Synthesis and Biological Activities
}

Stephen J. Mills, Ana M. Rossi, Vera Konieczny, Daniel Bakowski, Colin W. Taylor, and Barry V. L. Potter*

Cite This: J. Med. Chem. 2020, 63, 3238-3251

Read Online

ACCESS | LW Metrics \& More | 国 Article Recommendations

Supporting Information

ABSTRACT: Analogues of the $\mathrm{Ca}^{2+}$-releasing intracellular messenger D-myoinositol 1,4,5-trisphosphate $\left[1, \operatorname{Ins}(1,4,5) \mathrm{P}_{3}\right]$ are important synthetic targets. Replacement of the $\alpha$-glucopyranosyl motif in the natural product mimic adenophostin 2 by D-chiro-inositol in D-chiro-inositol adenophostin 4 increased the potency. Similar modification of the non-nucleotide $\operatorname{Ins}(1,4,5) \mathrm{P}_{3}$ mimic ribophostin 6 may increase the activity. D-chiro-Inositol ribophostin 10 was synthesized by coupling as building blocks suitably protected ribose 12 with L(+)-3-O-trifluoromethylsulfonyl-6-O-p-methoxybenzyl-1,2:4,5-di-O-isopropylidene-myo-inositol 11. Separable diastereoisomeric 3-O-camphanate esters of ( \pm )-6-O-p-methoxy-benzyl-1,2:4,5-di-O-isopropylidene-myo-inositol allowed the preparation of 11 . Selective trans-isopropylidene deprotection in coupled 13, then monobenzylation gave separable regioisomers 15 and $16 . p$ Methoxybenzyl group deprotection of 16, phosphitylation/oxidation, then

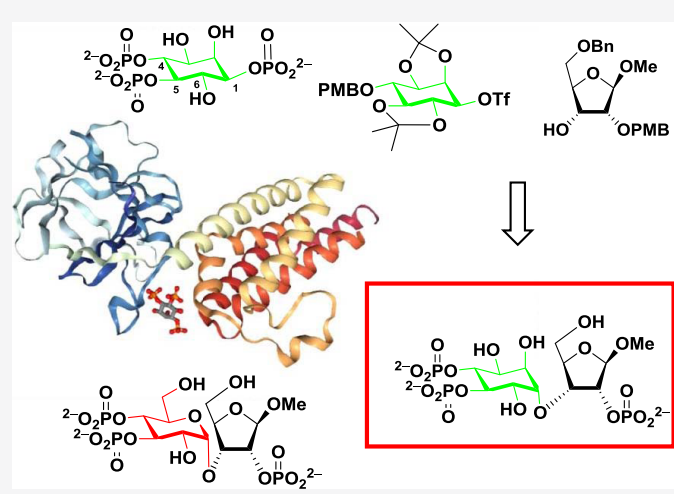
deprotection afforded 10, which was a full agonist in $\mathrm{Ca}^{2+}$-release assays; its potency and binding affinity for Ins $(1,4,5) \mathrm{P}_{3} \mathrm{R}$ were similar to those of adenophostin. Both 4 and 10 elicited a store-operated $\mathrm{Ca}^{2+}$ current $\mathrm{I}_{\mathrm{CRAC}}$ in patch-clamped cells, unlike Ins $(1,4,5) \mathrm{P}_{3}$ consistent with resistance to metabolism. D-chiro-Inositol ribophostin is the most potent small-molecule Ins $(1,4,5) \mathrm{P}_{3}$ receptor agonist without a nucleobase yet synthesized.

\section{INTRODUCTION}

Phospholipase C hydrolyzes phosphatidylinositol 4,5-bisphosphate to release the water-soluble second messenger, D-myoinositol 1,4,5-trisphosphate $\left[\operatorname{Ins}(1,4,5) \mathrm{P}_{3} 1\right.$, Figure 1]. Ins$(1,4,5) \mathrm{P}_{3}$ binds to the $\operatorname{Ins}(1,4,5) \mathrm{P}_{3}$-binding core (IBC) of its

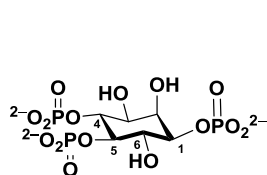

D-myo-Inositol 1,4,5-trisphosphate 1 (Ins $\left.(1,4,5) P_{3}\right)$

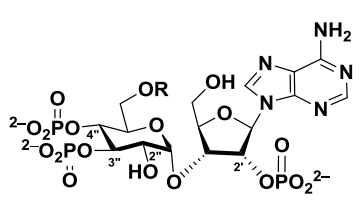

$\mathbf{R}=\mathbf{H} \quad$ Adenophostin $\mathbf{A}(\mathbf{2})$ $\mathbf{R}=\mathbf{A c}$ Adenophostin $\mathbf{B}(3)$

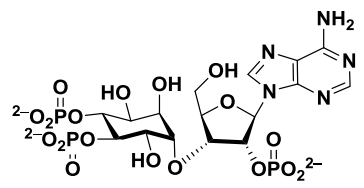

D-chiro-Inositol Adenophostin (4)

Figure 1. Structures of inositol trisphosphate 1, the adenophostins 2 and 3, and inositol adenophostin 4 . receptor $\left(\operatorname{Ins}(1,4,5) \mathrm{P}_{3} \mathrm{R}\right){ }^{1}$ a tetrameric structure with an intrinsic $\mathrm{Ca}^{2+}$-permeable pore that opens after $\operatorname{Ins}(1,4,5) \mathrm{P}_{3}$ binding. ${ }^{2-4}$ This allows $\mathrm{Ca}^{2+}$ to be released from intracellular stores to the cytosol to cause an increase in cytosolic $\mathrm{Ca}^{2+}$ concentration. Hence, $\operatorname{Ins}(1,4,5) \mathrm{P}_{3}$ links the many extracellular stimuli that activate phospholipase $\mathrm{C}$ to the $\mathrm{Ca}^{2+}$ signals that regulate diverse activities in animal cells. We have previously synthesized numerous modified ligands to probe their interactions with $\operatorname{Ins}(1,4,5) \mathrm{P}_{3} \mathrm{Rs}^{5-7}$ Such ligands include modifications or mimics of $\operatorname{Ins}(1,4,5) \mathrm{P}_{3}$ and also simplified benzene polyphosphate surrogates. ${ }^{6,7}$

The natural product glyconucleotides adenophostin A 2 and adenophostin B 3 (Figure 1) were isolated from fungal broths $^{8-10}$ and shown to be ca. 10-fold more potent than Ins $(1,4,5) \mathrm{P}_{3}$ in evoking $\mathrm{Ca}^{2+}$ release through each of the three mammalian Ins $(1,4,5) \mathrm{P}_{3} \mathrm{R}$ subtypes $\left(\operatorname{Ins}(1,4,5) \mathrm{P}_{3} \mathrm{R} 1-3\right) .{ }^{11}$

Received: November 29, 2019

Published: February 13, 2020 


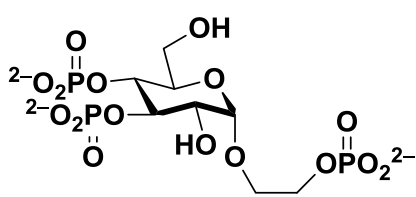

Glucopyranoside 2',3,4-trisphosphate (5)

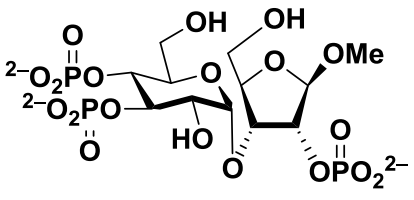

Ribophostin (6)

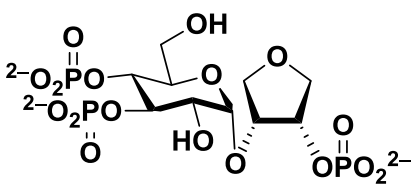

Furanophostin (7)

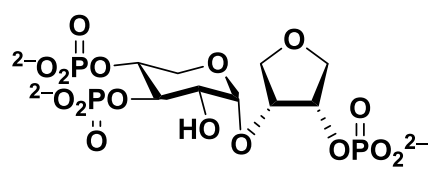

(8)

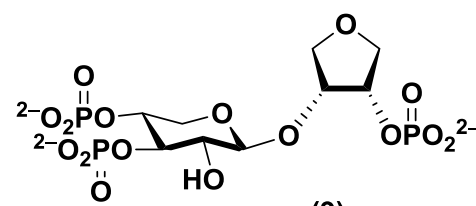

(9)

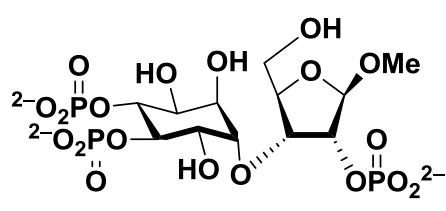

D-chiro-Inositol ribophostin

(10)

Figure 2. Structures of synthetic $\operatorname{Ins}(1,4,5) \mathrm{P}_{3}$ mimics based on part of adenophostin, including ribophostin 6 and inositol ribophostin 10.

Scheme 1. Coupling of the Suitably Protected Inositol Triflate 11 and Ribose 12 Building Blocks, Selective Deprotection, and Benzylation To Give the Separable Regioisomers 15 and 16 and Selective Deprotection of 16 To Afford Intermediate 17 for Phosphorylation

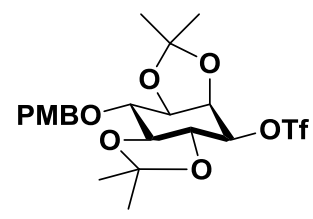

11

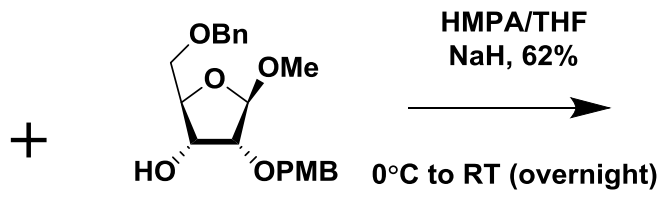

12
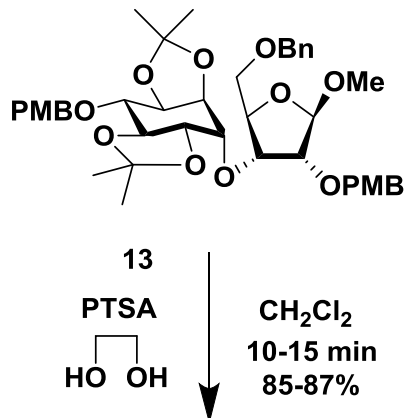

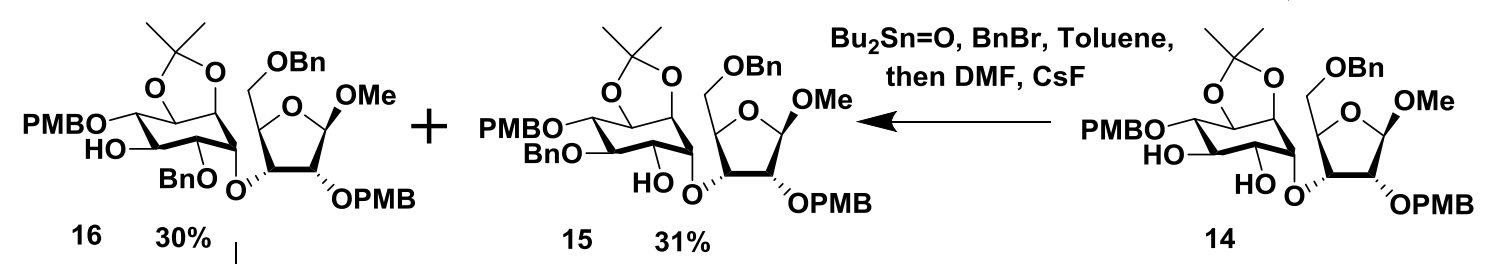

DDQ, $\mathrm{CH}_{2} \mathrm{Cl}_{2} / \mathrm{H}_{2} \mathrm{O}(15: 1)$ $63 \%$

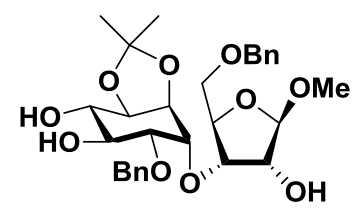

17

Their structure has inspired much synthetic work by us ${ }^{11-13}$ and others ${ }^{14-17}$ and provided numerous ligands with modifications at the phosphate groups, nucleobase motif, and at both sugars. ${ }^{11,18,19}$ However, the bisphosphorylated glucose moiety that is thought to mimic the key $\operatorname{Ins}(1,4,5) \mathrm{P}_{3}$ pharmacophore has never been replaced by a cyclitol bisphosphate structure until very recently. ${ }^{20}$ Here, the glucose motif of adenophostin A was replaced with D-chiro-inositol ${ }^{20}$ and thus the pyranose-furanose disaccharide linkage was replaced with a $s e c-s e c$ ether to give D-chiro-inositol adenophostin 4, which is nearly 2 -fold more potent than adenophostin $\mathrm{A}^{20}$

Our model for the interaction of adenophostin A with the Ins $(1,4,5) \mathrm{P}_{3}$ binding core (IBC; residues 224-604 in Ins$\left.(1,4,5) \mathrm{P}_{3} \mathrm{R} 1\right)^{21}$ is supported by mutagenesis ${ }^{22}$ and SAR analyses $^{13,19,23-25}$ and suggests that the glucose $3^{\prime \prime}, 4^{\prime \prime}$ - 
Scheme 2. Phosphitylation of 17, Oxidation of Resulting 18 to 19, and Complete Deprotection of 19 To Give the Target Inositol Ribophostin 10
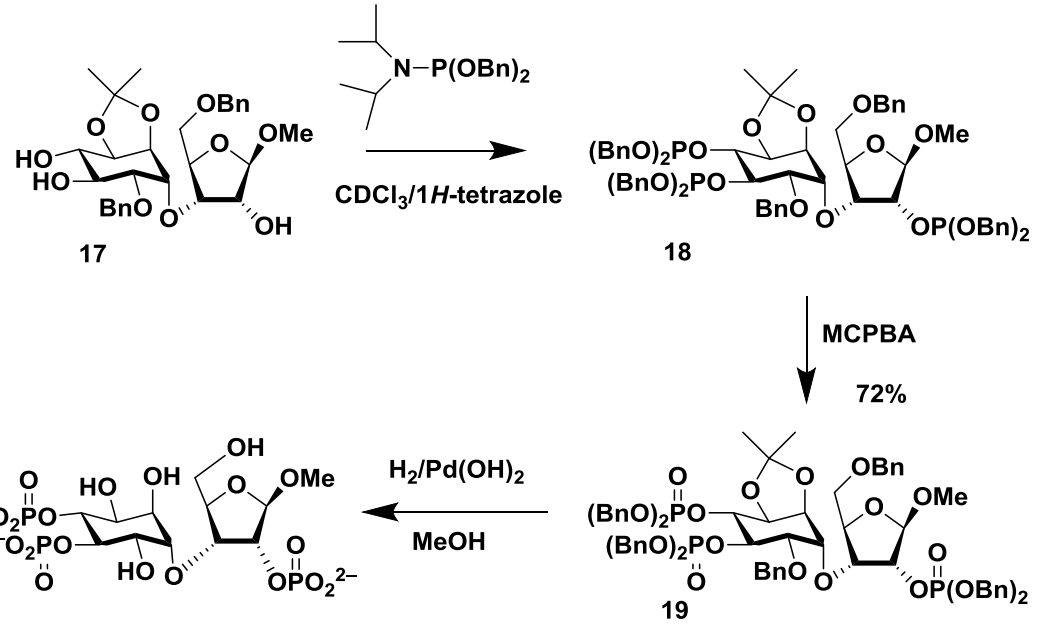

D-chiro-Inositol ribophostin 10

bisphosphate motif mimics the $\operatorname{Ins}(1,4,5) \mathrm{P}_{3}$ vicinal bisphosphate, while the $2^{\prime \prime}$-hydroxyl and $2^{\prime}$-phosphate groups mimic the nonessential 6-hydroxyl ${ }^{26}$ and the 1-phosphate of Ins $(1,4,5) \mathrm{P}_{3}$, respectively. A recently published cryo-electron microscopy (EM) structure ${ }^{2}$ of $\operatorname{Ins}(1,4,5) \mathrm{P}_{3} \mathrm{R} 1$ with bound adenophostin A hints at substantially different binding modes for this ligand. However, the ligand resolution in these protein structures is poor, the adenophostin A structure shown is incorrect (the pentose sugar is shown as xylose rather than a ribose derivative), and it is puzzling that the occupancy of the IBC by adenophostin A is very low in the presence of a saturating concentration of the ligand. ${ }^{2}$ Until these data are validated, we continue to work with our hypothesis that the glucose $2^{\prime \prime}$-hydroxyl and $3^{\prime \prime}, 4^{\prime \prime}$-bisphosphate triad motif of adenophostin $\mathrm{A}$ and related motifs in the corresponding disaccharide analogues discussed below mimic the respective 6-OH and 4,5-bisphosphate motifs of $\operatorname{Ins}(1,4,5) \mathrm{P}_{3}$ (Figure 1).

The simplest adenophostin A derivative designed to date is the glucopyranoside $2^{\prime}, 3,4$-trisphosphate $\left[\operatorname{Glc}\left(2^{\prime}, 3,4\right) \mathrm{P}_{3}\right](5$, Figure 2), in which the adenine and part of the ribose (C-1, C4 , and C-5 of ribose) were removed, leaving only an hydroxyethylphosphate moiety tethered at the $\alpha$-anomeric position of glucose. ${ }^{27,28} \mathrm{Glc}\left(2^{\prime}, 3,4\right) \mathrm{P}_{3}$ was ca. 10 -fold less potent than $\operatorname{Ins}(1,4,5) \mathrm{P}_{3}$ in releasing $\mathrm{Ca}^{2+}$ through $\operatorname{Ins}(1,4,5)$ $\mathrm{P}_{3} \mathrm{R}^{19}$ confirming the likely importance of the adenine and entire ribose sugar of adenophostin $\mathrm{A}$. Others confirmed similar activity for $\operatorname{Glc}\left(2^{\prime}, 3,4\right) \mathrm{P}_{3}$ and showed that it is not degraded by either of the enzymes that metabolize $\operatorname{Ins}(1,4,5)$ $\mathrm{P}_{3}$, the 5-phosphatase and 3-kinase. ${ }^{29}$ The ribose sugar tethered at the anomeric center of glucose was reintroduced to give ribophostin (6), which has also a $\beta$-OMe group replacing the adenine base at position-1 of ribose, and furanophostin (7), in which the anomeric OMe group and the methylene hydroxyl (at C-5 on ribose) were removed (Figure 2). The potency of both 6 and 7 was similar to that of Ins $(1,4,5) \mathrm{P}_{3} \cdot{ }^{11}$ Further pruning of furanophostin by removal of the pyranoside methylene hydroxyl group to give $\mathbf{8}$ reduced the potency to ca. 3 -fold below that of $\operatorname{Ins}(1,4,5) \mathrm{P}_{3}{ }^{11,30}$ Hence, ribophostin and furanophostin probably provide the best minimal disaccharide-based mimics of $\operatorname{Ins}(1,4,5) \mathrm{P}_{3}$. Compound 9 with the same phosphorylated tetrahydrofuran motif as $\mathbf{8}$, but with $\beta$-stereochemistry at the hemiacetal, was inactive, ${ }^{30}$ confirming an essential $\alpha$-stereochemical requirement for ribophostin.

Since D-chiro-inositol adenophostin 4 is more potent than adenophostin $A,{ }^{20}$ we speculated that replacing the glucose motif of ribophostin with a D-chiro-inositol derivative might also increase the potency of 6 . We now report a synthesis of $D-$ chiro-inositol ribophostin $\mathbf{1 0}$ and demonstrate that it both binds with greater affinity than ribophostin to $\operatorname{Ins}(1,4,5) \mathrm{P}_{3} \mathrm{R}$ and more potently evokes $\mathrm{Ca}^{2+}$ release, confirming the value of our approach. Moreover, the potency difference between 6 and 10 is considerably greater than that observed between 2 and 4, and unlike $\operatorname{Ins}(1,4,5) \mathrm{P}_{3}, \mathbf{1 0}$ is efficacious and exhibits metabolic resistance in an assay using patch-clamped whole cells.

\section{RESULTS AND DISCUSSION}

Chemistry. Previously, we discussed why a rigidly protected myo-inositol ring was key for the synthesis of Dchiro-inositol adenophostin ${ }^{20}$ and that a rigid inositol triflate L3-O-trifluoromethylsulfonyl-6-O-p-methoxybenzyl-1,2:4,5-di$O$-isopropylidene-myo-inositol 11 can undergo an $\mathrm{S}_{\mathrm{N}} 2$ reaction with a hard nucleophilic ribose derivative as its anion. Thus, triflate $\mathbf{1 1}$ (vide infra for an alternative formal identification of its absolute configuration as employed here) was coupled with the known suitably protected ribose derivative $\mathbf{1 2}^{20,31}$ in tetrahydrofuran (THF)-hexamethylphosphoramide (HMPA) with $\mathrm{NaH}$ as base ${ }^{20}$ (Scheme 1). The fully protected riboseinositol sec-sec ether derivative $\mathbf{1 3}$ was formed in a reasonable yield (62\%), and the more acid-sensitive trans-isopropylidene was then removed selectively and rapidly in the presence of ethylene glycol and catalytic $p$-toluenesulfonic acid (10-15 $\mathrm{min}$ ) to give diol 14 in $85 \%$ yield. The presence of the ribose now attached to the D-chiro-inositol derivative via an ether seemed to affect the ease with which the trans-isopropylidene acetal was removed by acid in the presence of ethylene glycol. Possibly, the axial ribose of derivative 13 may increase the strain of the trans-acetal and could facilitate its removal. Our previous studies ${ }^{32}$ showed that a longer reaction time (40 min) and more tetraol (from removal of both diol-protecting groups) resulted from a simple 1,2:4,5-di-O-isopropylidene 
Scheme 3. Determination of the Absolute Configuration of the Partially Protected D-1,2:4,5-di-O-isopropylidene-myo-inositol Diol 22 from the Separated Diastereoisomer 20

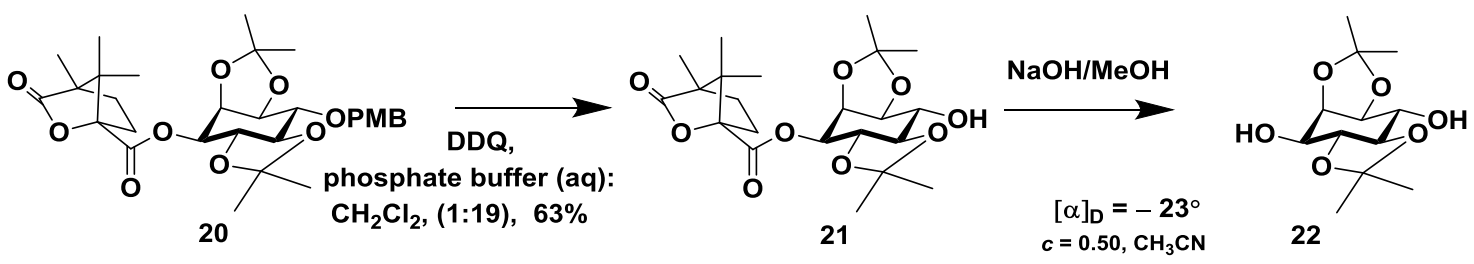

Lit $=-22^{\circ}$, enantiomer $+23.3^{\circ}$

derivative with allyl protection at the 3- and 6-positions. Monobenzylation was then achieved by the formation of a tin acetal on diol 14 in the presence of dibutyltin oxide. The addition of cesium fluoride and excess benzyl bromide gave the separable monobenzylated products 15 and 16 in roughly equal amounts, demonstrating that no selective monobenzylation was achieved under these conditions. Compound 16 was identified by ${ }^{1} \mathrm{H}$ NMR spectroscopy since it showed a double triplet where the proton at $\mathrm{C}-3-\mathrm{H}$ (of the D-chiro-inositol motif) flanked by two adjacent axial protons also had an extra coupling to the hydroxyl group $\mathrm{C}-3-\mathrm{OH}$ that exchanged with $\mathrm{D}_{2} \mathrm{O}$. If the exchangeable $\mathrm{OH}$ was at $\mathrm{C}-2-\mathrm{H}$, next to the axial ribose-inositol ether bond, there should be a double double doublet, which upon exchange should give a double doublet. The next step required the removal of the two $p$ methoxybenzyl groups. Deprotection under acidic conditions was not an option as this would also remove the cisisopropylidene moiety. Thus, 2,3-dichloro-5,6-dicyano-1,4benzoquinone (DDQ) in dichloromethane-water was used, giving the protected triol $\mathbf{1 7}$ for phosphorylation in a reasonable yield (63\%) after $1 \mathrm{~h}$ (Scheme 1$)$.

Phosphitylation of $\mathbf{1 7}$ in $\mathrm{CDCl}_{3}$ provided trisphosphite $\mathbf{1 8}$ (Scheme 2). ${ }^{31} \mathrm{P}$ NMR spectroscopy showed the expected $\mathrm{AB}$ system for the vicinal bisphosphite motif, ${ }^{33}$ with one half centered around $\delta=140.5$ and the other at $\delta=138.8, J=6.0$ $\mathrm{Hz}$. Intermediate 18 was then oxidized with $m \mathrm{CPBA}$ to give the trisphosphate 19 in good yield (72\%). Compound 19 was then deblocked at room temperature using palladium hydroxide and hydrogen. The best deprotection method was to leave the mixture stirring for 1 week at room temperature; the isopropylidene group was removed due to the acidic nature of the adjacent phosphates. Purification of the product, first using a gradient of triethylammonium bicarbonate (TEAB) buffer, then over RP18 resin, provided the target trisphosphate 10 in $43 \%$ yield. The product was quantified for biological assays after RP18 purification using the Briggs test. ${ }^{34,35}$

The synthesis and separation of camphanate 20, leading to compound 22 and the more polar camphanate derivative (not shown but used to synthesize compound 11), were discussed previously. ${ }^{20}$ The $p$-methoxybenzyl (PMB) group of 20 was first removed using DDQ in a dichloromethane-phosphate buffer. Since $\mathbf{2 2}$ is highly soluble in both dichloromethane and water, it would be difficult to extract and purify. The reaction was also buffered because the trans-4,5-isopropylidene group may be easily removed from 20 in its conversion to 21 in the presence of the acidic phenol $\mathrm{DDQH}_{2}$. The camphanate derivative was then deacylated in methanolic sodium hydroxide. The less polar diastereoisomer was identified as being a derivative of $\mathrm{D}-1,2: 4,5$-di-O-isopropylidene-myo-inositol 22, by virtue of its rotation, and close to the literature values. $^{36-38}$ The other, more polar diastereoisomeric campha- nate was isolated by chromatography, then deacylated, as previously described, ${ }^{20}$ giving L-6-O-p-methoxybenzyl-1,2:4,5di-O-isopropylidene-myo-inositol, and used for the synthesis of inositol triflate 11 (Scheme 3).

Biology. In permeabilized avian DT40 cells expressing only rat $\operatorname{Ins}(1,4,5) \mathrm{P}_{3} \mathrm{R} 1$ (DT40-Ins $(1,4,5) \mathrm{P}_{3} \mathrm{R} 1$ cells), maximally effective concentrations of $\operatorname{Ins}(1,4,5) \mathrm{P}_{3} \mathbf{1}$, ribophostin 6 , and D-chiro-inositol ribophostin 10 each released the same fraction (ca. $65 \%$ ) of the intracellular $\mathrm{Ca}^{2+}$ stores. $\operatorname{Ins}(1,4,5) \mathrm{P}_{3}$ and ribophostin were equipotent, but D-chiro-inositol ribophostin was ca. 7-fold more potent than ribophostin (Figure 3 and

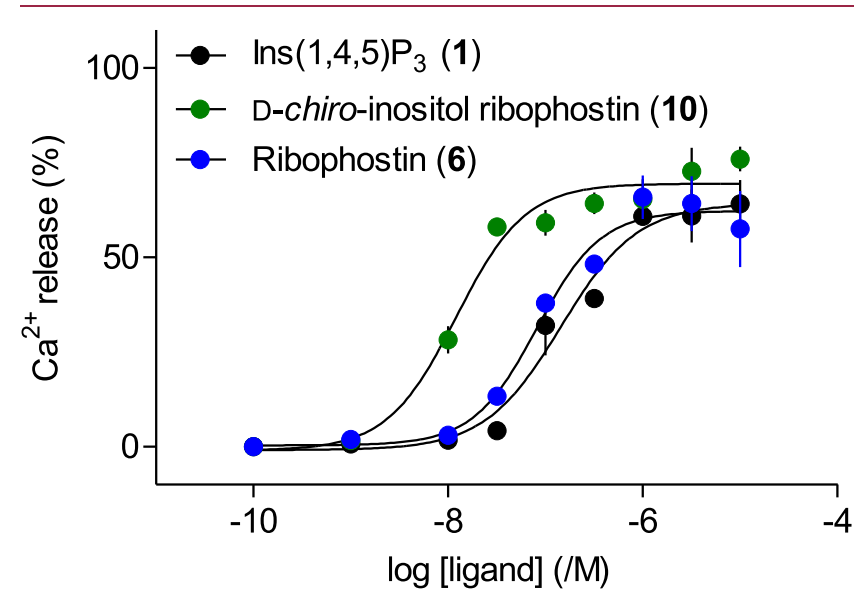

Figure 3. Effects of ligands on $\mathrm{Ca}^{2+}$ release from the intracellular stores of permeabilized DT40-Ins $(1,4,5) \mathrm{P}_{3} \mathrm{R} 1$ cells. Results, expressed as a percentage of the $\mathrm{Ca}^{2+}$ content of the intracellular stores, show the effects of the indicated concentrations of each ligand. Mean \pm SEM from three independent experiments (summarized in Table 1).

Table 1). Similar results were obtained from analyses of $\mathrm{Ca}^{2+}$ release in permeabilized mammalian cells expressing only rat Ins $(1,4,5) \mathrm{P}_{3} \mathrm{R} 1$ (HEK-Ins $(1,4,5) \mathrm{P}_{3} \mathrm{R} 1$ cells), where 1, 2, 6 and 10 each released the same fraction (ca. 70\%) of the intracellular stores, and D-chiro-inositol ribophostin was 3fold more potent than ribophostin and only 2 -fold less potent than adenophostin A (Figure 4 and Table 2).

In equilibrium-competition binding assays using $\left[{ }^{3} \mathrm{H}\right]$ Ins $(1,4,5) \mathrm{P}_{3}$ and cerebellar membranes, which express large amounts of $\operatorname{Ins}(1,4,5) \mathrm{P}_{3} \mathrm{R} 1 \mathrm{~s}$, the affinity of D-chiro-inositol ribophostin for $\operatorname{Ins}(1,4,5) \mathrm{P}_{3} \mathrm{Rs}$ (defined by the equilibrium dissociation constant, $K_{\mathrm{d}}$ ) was 2.3-fold greater than that of ribophostin and only 2 -fold lower than that of adenophostin A (Figure 5 and Table 2). As reported previously, ${ }^{39}$ a comparison of the ratio of the concentrations of ligand required to evoke half-maximal $\mathrm{Ca}^{2+}$ release $\left(\mathrm{EC}_{50}\right)$ and occupy $50 \%$ of Ins $(1,4,5) \mathrm{P}_{3} \mathrm{Rs}\left(K_{\mathrm{d}}\right)$, the $\mathrm{EC}_{50} / K_{\mathrm{d}}$ ratio, can be used to report efficacy, that is, the ability of a ligand to activate $\operatorname{Ins}(1,4,5) \mathrm{P}_{3} \mathrm{R}$ 
Table 1. Effects of Ligands on $\mathrm{Ca}^{2+}$ Release through Ins $(1,4,5) P_{3} R 1$ Expressed in DT40 Cells ${ }^{a}$

$\begin{array}{lccc} & \mathrm{pEC}_{50}\left(\mathrm{EC}_{50}\right)(\mathrm{nM}) & \mathrm{Ca}^{2+} \text { release } \\ & 6.88 \pm 0.18(133) & 63 \pm 5 & 2.0 \pm 0.8 \\ \text { Ins }(1,4,5) \mathrm{P}_{3}(\mathbf{1}) & 7.93 \pm 0.06(12) & 70 \pm 2 & 1.6 \pm 0.4 \\ \begin{array}{c}\text { D-chiro-inositol } \\ \text { ribophostin (10) }\end{array} & 7.05 \pm 0.10(88) & 64 \pm 7 & 1.4 \pm 0.4\end{array}$

${ }^{a}$ Results (from Figure 3) show mean \pm standard error of the mean (SEM) $\left(\mathrm{pEC}_{50}, \mathrm{Ca}^{2+}\right.$ release (\%) and $\left.h\right)$ and means $\left(\mathrm{EC}_{50}\right)$ from three independent experiments. $\mathrm{EC}_{50}$, half-maximal effective concentration; $\mathrm{pEC}_{50},-\operatorname{logEC_{50}} ; h$, Hill coefficient. $* P<0.05$ was considered significant. None of the mean values for $\mathrm{Ca}^{2+}$ release or $h$ differed significantly between ligands. There were significant differences between $\mathrm{pEC}_{50}$ values for $\operatorname{Ins}(1,4,5) \mathrm{P}_{3}$ versus D-chiro-inositol ribophostin and ribophostin versus D-chiro-inositol ribophostin 10.

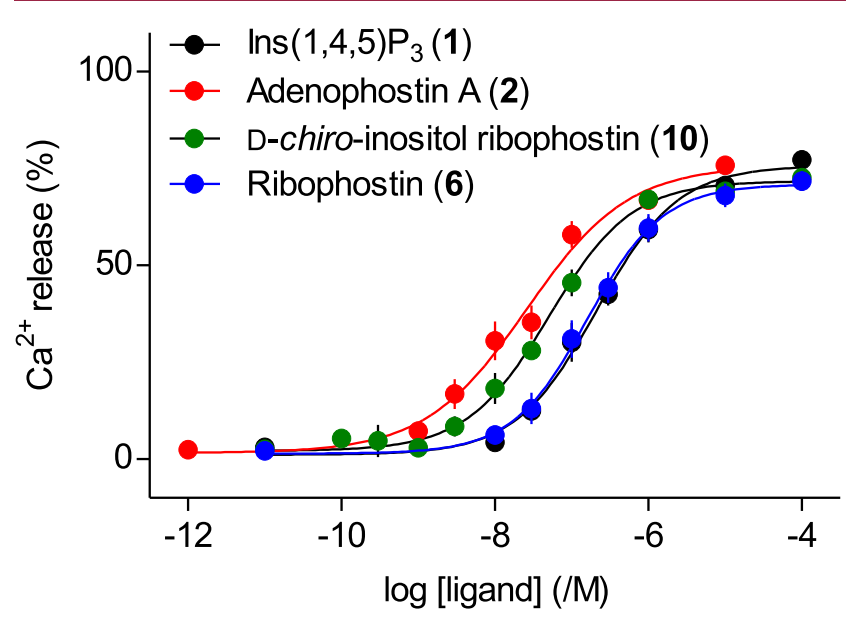

Figure 4. Effects of ligands on $\mathrm{Ca}^{2+}$ release from the intracellular stores of permeabilized HEK-Ins $(1,4,5) \mathrm{P}_{3} \mathrm{R} 1$ cells. Results show mean \pm SEM from nine independent experiments, each performed in duplicate (summarized in Table 2).

once it has bound. The ratios were similar for all four ligands (Table 2), and since Ins $(1,4,5) \mathrm{P}_{3}$ and adenophostin A are full agonists, ${ }^{39}$ we conclude that ribophostin and D-chiro-inositol ribophostin are also full agonists.

These results demonstrate that replacing the glucose moiety of ribophostin with an inositol substantially increases the affinity of the resulting ligand, D-chiro-inositol ribophostin, for Ins $(1,4,5) \mathrm{P}_{3}$ Rs without compromising efficacy. D-chiro-Inositol

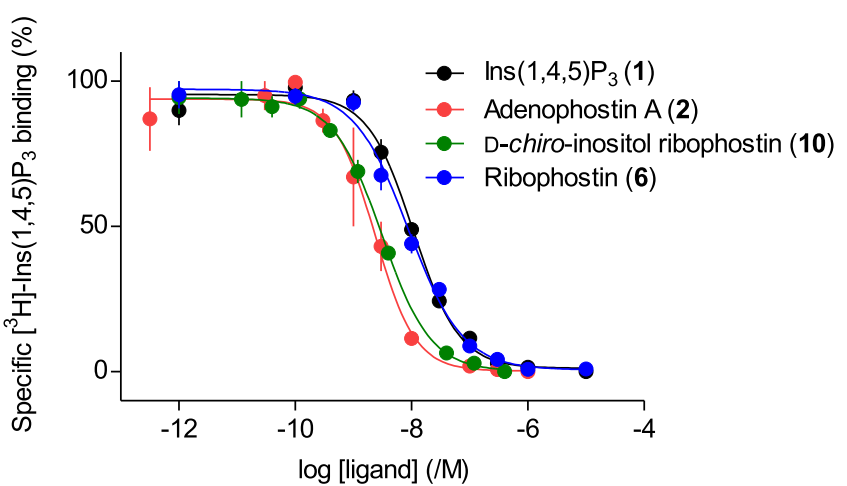

Figure 5. Equilibrium-competition binding to cerebellar membranes using $\left[{ }^{3} \mathrm{H}\right]-\operatorname{Ins}(1,4,5) \mathrm{P}_{3}$ and the indicated concentrations of competing ligands. Results show mean \pm SEM from three independent experiments (summarized in Table 2).

ribophostin is the most potent ribophostin-type analogue synthesized to date.

Structure-Activity Relationships (SAR). Structureactivity relationship (SAR) parameters are summarized in Figure 6, and those for Ins $(1,4,5) \mathrm{P}_{3}$ have been well rehearsed $^{5,7}$ (Figure 6a). Adenophostin A data (Figure 6b) are also more relevant for considering the activity of $\mathbf{1 0}$ since it possesses the core disaccharide motif of ribophostin (Figure 6c). Figure 6 demonstrates that apparently similar structural modifications do not necessarily correlate across the three ligand classes. Since compound 10 is a hybrid of $\operatorname{Ins}(1,4,5) \mathrm{P}_{3}$ and ribophostin and approaching the potency of adenophostin for $\mathrm{Ca}^{2+}$ release, a summary of the various strategic functional groups and the effect of various positional modifications within these molecules is given in Figure 6.

Exploration of a potential "supra-optimal" phosphate group in adenophostin $\mathrm{A}$ led to the synthesis of phosphorylated disaccharides ${ }^{40}$ with conformational restriction, for example, sucrose 3,4,3'-trisphosphate (23), $\alpha, \alpha^{\prime}$-trehalose 2,4,3', $4^{\prime}$ tetrakisphosphate (24), and $\alpha, \alpha^{\prime}$-trehalose $3,4,3^{\prime}, 4^{\prime}$-tetrakisphosphate (25) (Figure 7). Comparing the three structures for optimal positioning of the single phosphate to that of the 2phosphate on the ribose of ribophostin, compound 23 is 25 fold less potent for $\mathrm{Ca}^{2+}$ release, and therefore with the phosphate not in an optimal position. Compound 24 is only 6fold weaker for $\mathrm{Ca}^{2+}$ release than ribophostin, ${ }^{40}$ and compound 25 is 11.5-fold weaker for $\mathrm{Ca}^{2+}$ release and less potent than 24 .

The Ins $(1,4,5) \mathrm{P}_{3} \mathrm{R}$ binding ${ }^{21}$ model suggested mimicry of the key structural components of $\operatorname{Ins}(1,4,5) \mathrm{P}_{3}$, with binding

Table 2. Comparison of Binding and Functional Effects of $\operatorname{Ins}(1,4,5) P_{3} R$ Ligands ${ }^{a}$

\begin{tabular}{|c|c|c|c|c|c|c|}
\hline & \multirow{2}{*}{$\frac{\mathrm{Ca}^{2+} \text { release }}{\mathrm{pEC}_{50}\left(\mathrm{EC}_{50}\right)(\mathrm{nM})}$} & \multirow[b]{2}{*}{ release $(\%)$} & \multirow[b]{2}{*}{$h$} & \multicolumn{2}{|c|}{ binding } & \multirow[b]{2}{*}{$\mathrm{EC}_{50} / K_{\mathrm{d}}(95 \% \mathrm{CI})$} \\
\hline & & & & $\mathrm{p} K_{\mathrm{d}}\left(K_{\mathrm{d}}\right)(\mathrm{nM})$ & $h$ & \\
\hline $\operatorname{Ins}(1,4,5) \mathrm{P}_{3}(1)$ & $6.68 \pm 0.09(209)$ & $76 \pm 2$ & $1.0 \pm 0.1$ & $8.06 \pm 0.03(8.71)$ & $1.1 \pm 0.2$ & $24(11-56)$ \\
\hline adenophostin A (2) & $7.57 \pm 0.11(27)$ & $76 \pm 3$ & $1.0 \pm 0.3$ & $8.86 \pm 0.14(1.38)$ & $1.2 \pm 0.2$ & $19(6-58)$ \\
\hline D-chiro-inositol ribophostin (10) & $7.28 \pm 0.12(52)$ & $71 \pm 1$ & $1.1 \pm 0.1$ & $8.49 \pm 0.03(3.24)$ & $1.0 \pm 0.1$ & $16(5-49)$ \\
\hline ribophostin (6) & $6.81 \pm 0.10(155)$ & $72 \pm 2$ & $1.0 \pm 0.1$ & $8.12 \pm 0.03(7.59)$ & $0.9 \pm 0.1$ & $20(8-51)$ \\
\hline
\end{tabular}

${ }^{a}$ Summary of the effects of ligands on $\mathrm{Ca}^{2+}$ release from the intracellular stores of HEK-Ins $(1,4,5) \mathrm{P}_{3} \mathrm{R} 1$ cells (from Figure 4) and on $\left[{ }^{3} \mathrm{H}\right]$ Ins $(1,4,5) \mathrm{P}_{3}$ binding to cerebellar membranes (from Figure 5). Results show mean $\pm \mathrm{SEM}\left(\mathrm{pEC}_{50}, \mathrm{Ca}^{2+}\right.$ release $(\%), \mathrm{p} K_{\mathrm{d}}$ and $\left.h\right)$ and means $\left(\mathrm{EC}_{50}\right.$, $K_{\mathrm{d}}$ ) from nine $\left(\mathrm{Ca}^{2+}\right.$ release) or three (binding) experiments. $\mathrm{EC}_{50} / K_{\mathrm{d}}$ ratios show means with $95 \%$ confidence intervals $(\mathrm{CI}) . P<0.05$ was considered significant. None of the mean values for $\mathrm{Ca}^{2+}$ release, $h$ or $\mathrm{EC}_{50} / K_{\mathrm{d}}$ ratios, differed significantly between ligands. There were significant differences between mean $\mathrm{pEC}_{50}$ values for $\operatorname{Ins}(1,4,5) \mathrm{P}_{3}$ versus adenophostin $\mathrm{A}$, $\operatorname{Ins}(1,4,5) \mathrm{P}_{3}$ versus D-chiro-inositol ribophostin, adenophostin $\mathrm{A}$ versus ribophostin and D-chiro-inositol ribophostin versus ribophostin; and between mean $\mathrm{p} K_{\mathrm{d}}$ values for $\operatorname{Ins}(1,4,5) \mathrm{P}_{3}$ versus adenophostin $A$, Ins $(1,4,5) \mathrm{P}_{3}$ versus $\mathrm{D}$-chiro-inositol ribophostin, and adenophostin A versus ribophostin. 
C-3-OH enhances binding, but less important than C-6-OH. F-replacement, slight activity reduction. Equatorial or axial phosphate massive reduction in potency.

4,5-Bisphosphate is critical for $\mathrm{Ca}^{2+}$-release activity. Cyclic pyrophosphate between 4- and 5- abolishes activity.

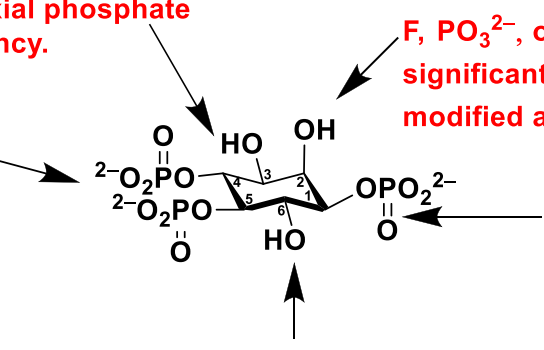

$6-\mathrm{OH}$ is critical for binding and may affect the 5 -phosphate in some way. Deletion or inversion reduces the activity and no phosphate or bulky group can be introduced at this position.

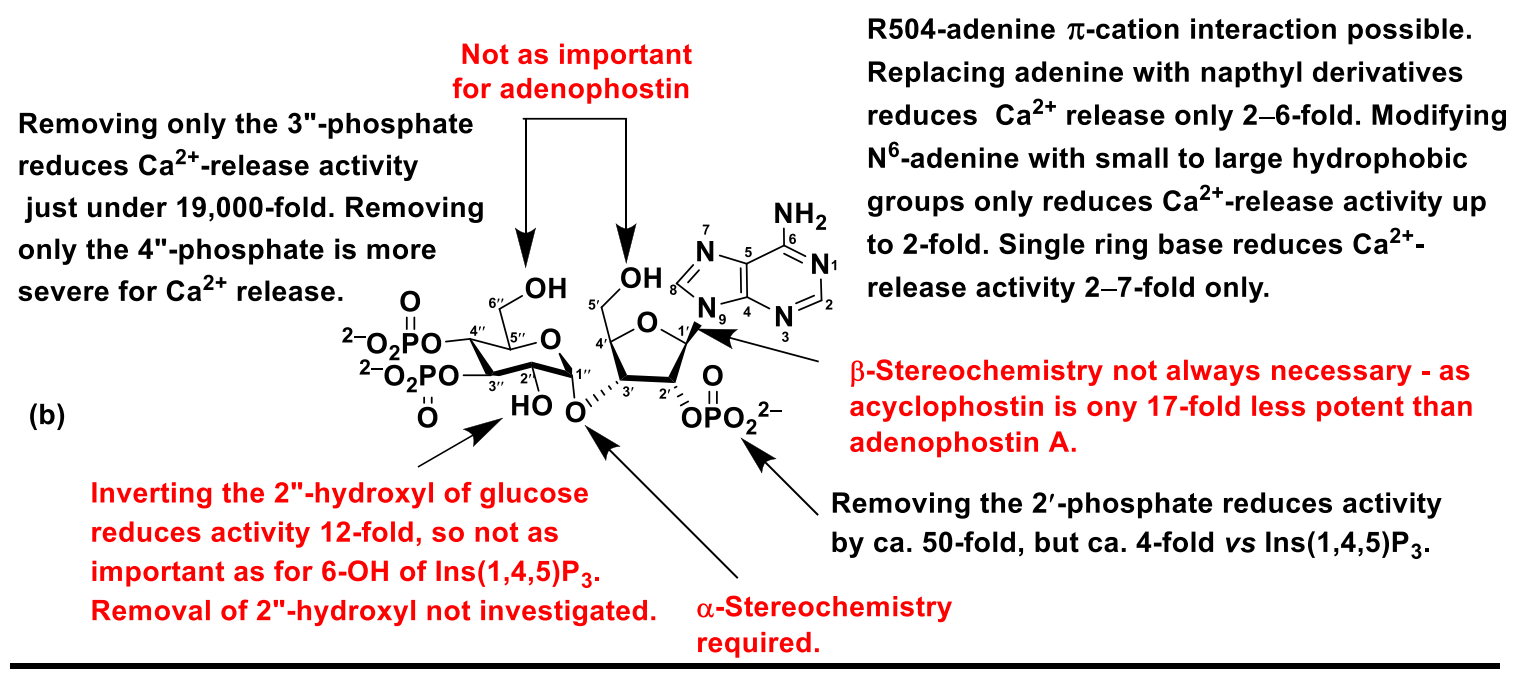

(c)
The 5'-hydroxymethyl
Furanophostin, a compound without group not greatly $\mathrm{OMe}$ and $-\mathrm{CH}_{2} \mathrm{OH}$ groups does not significant in ribophostin. reduce $\mathrm{Ca}^{2+}$-release activity.

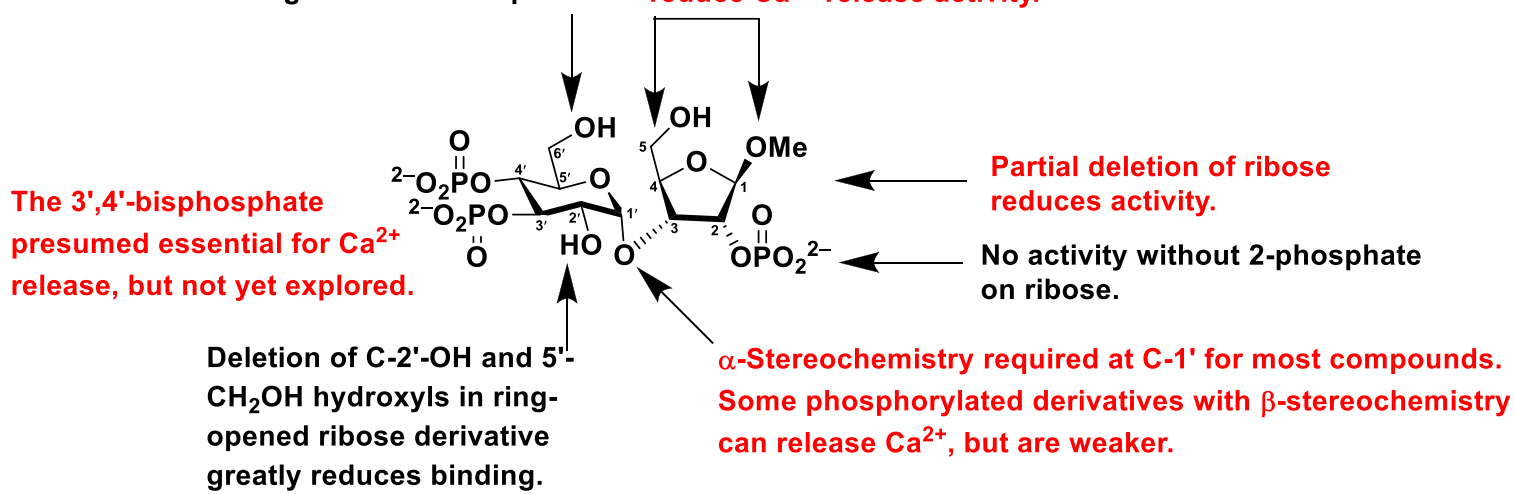

Figure 6. Comparative summary of structure-activity parameters for analogues of (a) $\operatorname{Ins}(1,4,5) \mathrm{P}_{3},(b)$ adenophostin $A$, and (c) ribophostin illustrating major differences between the three ligand classes.

enhanced by the adenine base of adenophostin A interacting with Arg504. This is supported by mutagenesis data. ${ }^{12}$ The N6 position can be modified with little effect on activity ${ }^{21}$ and, while substantial modifications to the adenine base are tolerated, ${ }^{16,17,41}$ a bicyclic ring system is preferred. The two sugar hydroxymethyl groups are not important for potent activity, and ribose $2^{\prime}$-phosphate, while not critical, mimics the 1-phosphate of $\operatorname{Ins}(1,4,5) \mathrm{P}_{3}{ }^{11}$ The idea that this phosphate may facilitate binding in a supra-optimal fashion was discounted in favor of synergy between the adenine base and the phosphate group. ${ }^{12}$ The vicinal glucose bisphosphate is critical for potent activity, and removing either the $3^{\prime}$ phosphate or $4^{\prime \prime}$-phosphate massively decreases activity, but the $4^{\prime \prime}$-phosphate is less critical. ${ }^{11,13,22}$ Acyclophostin 26, an analogue that can be viewed as either an "opened" ribose or similar to 5 but with an additional adenine motif, is only 14- 


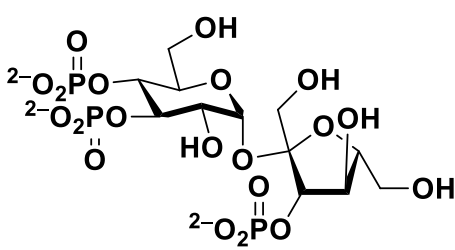

23
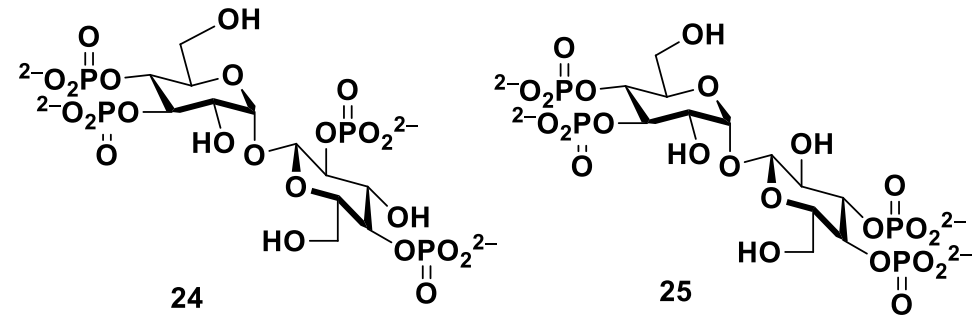

Figure 7. Disaccharide polyphosphate agonists to explore conformational restriction.

17-fold less potent than adenophostin $\mathrm{A}^{42}$ and a $\mathrm{pH}$-dependent partial agonist. Transposing the 3 "-phosphate of adenophostin to the glucose $2^{\prime \prime}$-hydroxyl group gave a $2,2^{\prime}, 4$-trisphosphate 27 (Figure 8) that is surprisingly only 12 -fold less potent than
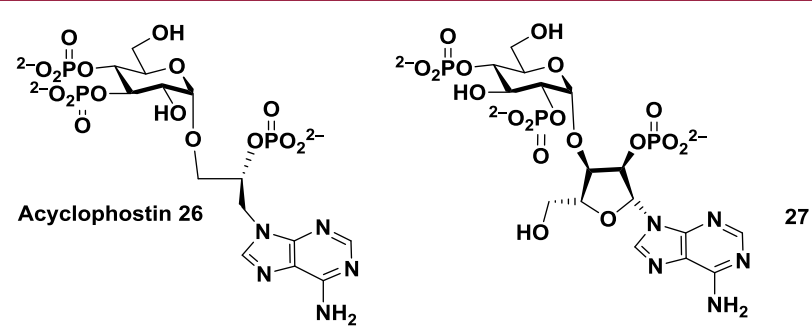

Figure 8. Structures of the ribose ring-opened adenophostin analogue acyclophostin 26 and the active regioisomeric 2,2',4-trisphosphate adenophostin analogue 27 .

Ins $(1,4,5) \mathrm{P}_{3}$ and was perhaps the most surprising of all analogues to date. ${ }^{42}$ However, with an understanding of the structure of the IBC, this could subsequently be rationalized without disturbing the original binding model. ${ }^{13,21}$

Figure $6 \mathrm{c}$ illustrates the SAR for ribophostin for which modifications have been synthesized. The skeletal tetrahydrofuran derivative such as $\mathbf{8}$ (Figure 2) exhibits a potency close to Ins $(1,4,5) \mathrm{P}_{3}$ and ribophostin. ${ }^{11}$ There is little effect when the primary hydroxymethyl groups are removed either individually or together. ${ }^{19}$ If 3,4-bisphosphate is replaced with bis-phosphorothioate, ${ }^{19} \mathrm{EC}_{50}$ drops 5-fold.

Compound $\mathbf{2 8}$ (Figure 9) is a diastereoisomer of compound 8 (Figure 2). 28 has a very low potency in $\mathrm{Ca}^{2+}$-release assays, ${ }^{19,30}$ and 29 , with $\beta$-stereochemistry, releases $\mathrm{Ca}^{2+}$ with only $\sim 19$-fold lesser potency than $\operatorname{Ins}(1,4,5) \mathrm{P}_{3} \cdot{ }^{19,30}$ The reasons for this are unclear. Xylopyranoside $2^{\prime}, 3,4$-trisphos- phate 30 has 17 -fold lower affinity than $\operatorname{Ins}(1,4,5) \mathrm{P}_{3}$, but 2deoxy-xylopyranoside $2^{\prime}, 3$,4-trisphosphate 31 has 2000-fold lower affinity, indicating the importance of the pyranose 2hydroxyl group (equivalent to the C-6-OH of $\left.\operatorname{Ins}(1,4,5) \mathrm{P}_{3}\right){ }^{43}$

Thus, all three ligands exhibit diverse SAR features and, while these structural modifications on activity individually have been extensively reviewed, ${ }^{5,44}$ they have not before been juxtaposed between analogue classes as in Figure 6.

Two sterically constrained phosphorylated epimers $(R)-32$ and $(S)-33$ and the "spirophostin" compounds $(R)-34$ and $(S)$ 35 were also synthesized (Figure 10). ${ }^{45,46} 32$ and 33 were,
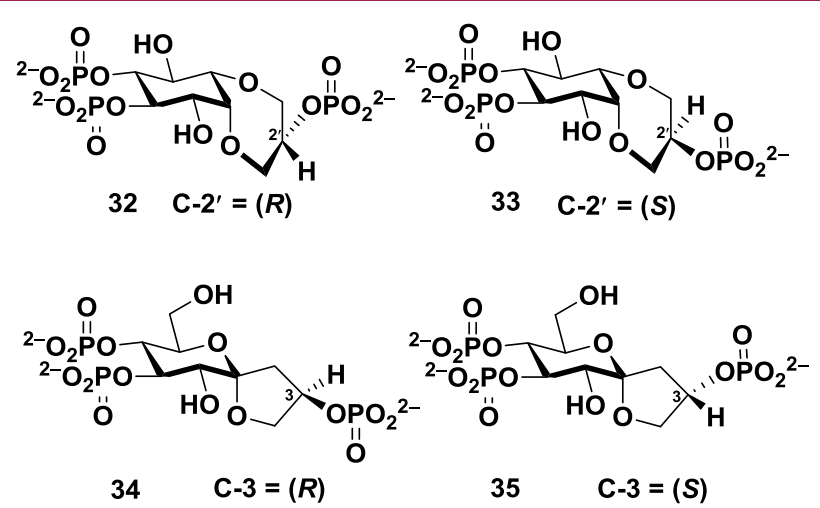

Figure 10. Synthetic sterically constrained epimers to explore the conformational restriction at the potentially supraoptimal nonvicinal phosphate group.

respectively, 18 - and 14-fold less potent than $\operatorname{Ins}(1,4,5) \mathrm{P}_{3}$, and 34 and 35 were 6-fold and ca. 12-fold less potent for $\mathrm{Ca}^{2+}$. release. No compound (28-35) is as potent as ribophostin, which behaves similarly to $\operatorname{Ins}(1,4,5) \mathrm{P}_{3}$.
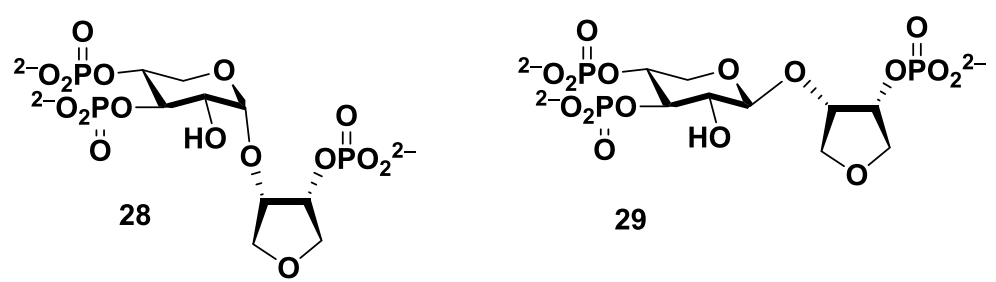

29
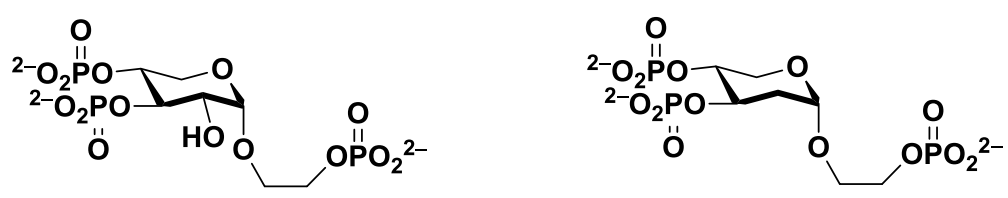

30

Figure 9. Structures of minimal xylopyranoside-based agonists. 

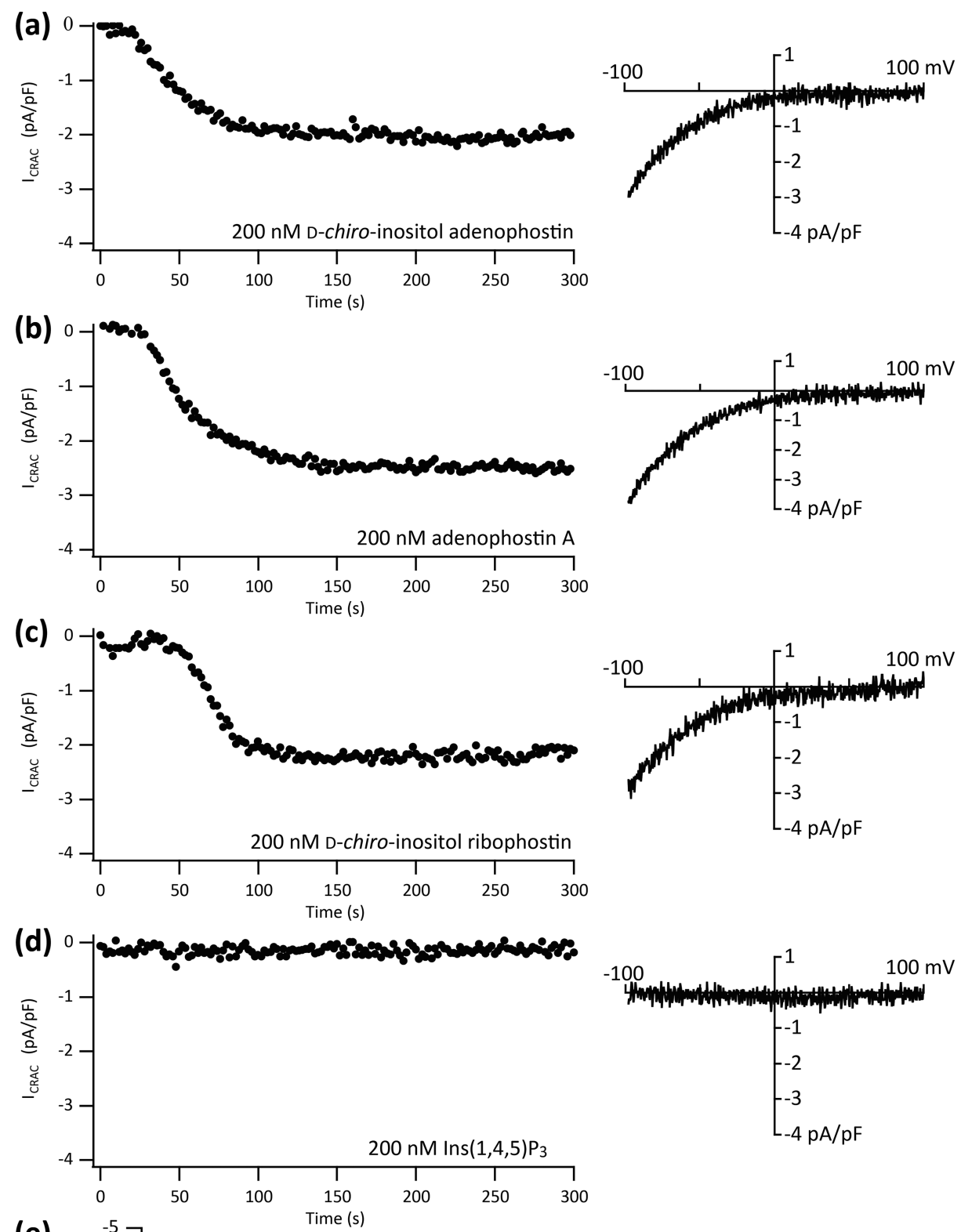

(e)

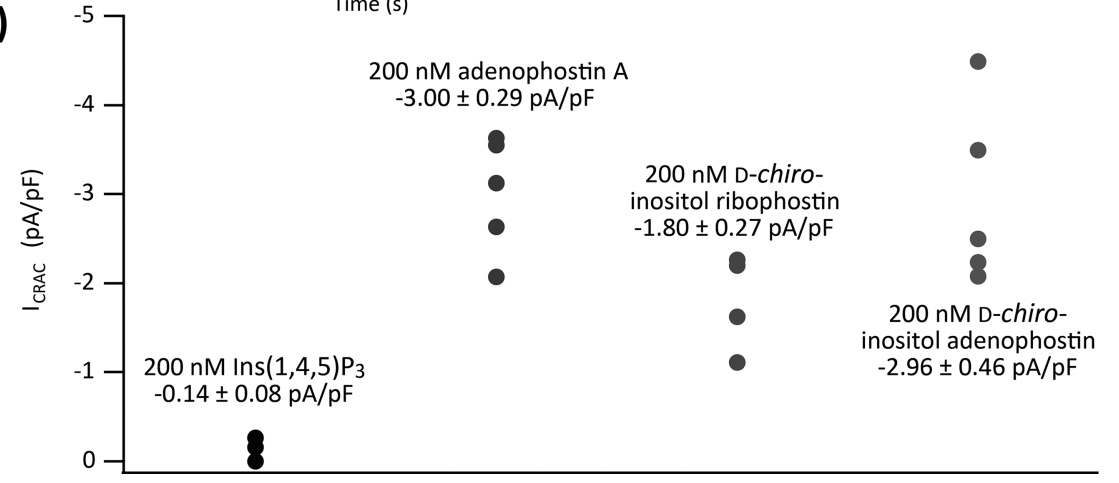

Figure 11. Activation of the store-operated $\mathrm{Ca}^{2+}$ current $\mathrm{I}_{\mathrm{CRAC}}$ in $\mathrm{RBL}-2 \mathrm{H} 3$ cells following whole-cell dialysis with the Ins $(1,4,5) \mathrm{P}_{3} \mathrm{R}$ ligands $(\mathrm{a}) \mathrm{D}-$ chiro-inositol adenophostin 4, (b) adenophostin A 2, (c) D-chiro-inositol ribophostin 10, and (d) Ins $(1,4,5) \mathrm{P}_{3} 1$. Representative time courses (measured at $\div 80 \mathrm{mV}$ ) and current-voltage relationships are shown. $200 \mathrm{nM}$ Ins $(1,4,5) \mathrm{P}_{3}$ routinely failed to evoke a detectable whole-cell current. Data are summarized in (e) as mean \pm SEM, three to five cells for each condition.

D-chiro-Inositol adenophostin 4 was the first adenophostin A analogue of its kind to possess a glucose-to-inositol replacement, offering increased possibilities for structural diversity and engineering by virtue of its extra hydroxyl group replacing the pyranoside oxygen. It was more active than adenophostin A itself, albeit by a relatively modest margin. ${ }^{20}$ The simplest interpretation is that the D-chiro-inositol trisphosphate moiety of $\mathbf{4}$ better fits into the receptor than the glucose-based mimic of adenophostin A, consistent with our original binding model. ${ }^{21}$ Similarly, D-chiro-inositol 
ribophostin 10 is the first ribophostin analogue of its kind where the glucose 3,4-bisphosphate moiety is replaced with a D-chiro-inositol 3,4-bisphosphate unit. Different chemistry is used to form the hemiacetal of ribophostin 6 and the sec-sec ether of 10. The main difference between $\mathbf{6}$ and $\mathbf{1 0}$ is that the 5- and 6-positions of D-chiro-inositol (mimicking the 3- and 2positions of $\operatorname{Ins}(1,4,5) \mathrm{P}_{3}$ in our $\left.\operatorname{model}^{20}\right)$ replace the 5hydroxymethyl group and the pyranoside oxygen. Figure $6 \mathrm{a}-\mathrm{c}$ shows how individual positions on $\operatorname{Ins}(1,4,5) \mathrm{P}_{3}$, ribophostin, and adenophostin influence activity. It might be expected from this that there would be little gain in activity by replacing a pyranoside oxygen by a $\mathrm{C} 2-\mathrm{OH}$ group. Similarly, the loss of a hydroxymethyl group would not be expected to greatly affect activity, and its replacement by an inositol hydroxyl group should not have any marked effect.

In practice, however, the effects are more marked than expected and exceed those observed in the case of 4 . When the potency of adenophostin A $\mathbf{2}$ is compared to that of its counterpart inositol adenophostin 4, 4 is some 1.6-fold more potent in $\mathrm{Ca}^{2+}$-release assays. ${ }^{20}$ Similarly, replacing the glucose unit of ribophostin with an inositol motif enhances potency, but more appreciably. Thus, in $\mathrm{Ca}^{2+}$-release assays in two systems, inositol ribophostin 10 was ca. 7- and 3-fold more potent than ribophostin 6 and 11-fold and 4-fold more potent than $\operatorname{Ins}(1,4,5) \mathrm{P}_{3}$, approaching adenophostin $\mathrm{A}$ in its activity. 10 also had a greater affinity than $\operatorname{Ins}(1,4,5) \mathrm{P}_{3}$ for $\operatorname{Ins}(1,4,5)$ $\mathrm{P}_{3} \mathrm{R} 1$. Thus, glucopyranoside replacement can further increase the biological activity, presumably through a better fit of the new inositol bisphosphate moiety with the receptor than the original glucose bisphosphate mimic derived from adenophostin A. Perhaps also the lack of a base motif as in $\mathbf{4}$ allows more conformational flexibility for $\mathbf{6}$ in its search for an optimal binding conformation. It is conceivable, therefore, from our binding model $^{21}$ and related work implicating a specific role for the adenine base of adenophostin ${ }^{12,13,18,22,23}$ that conformational movement of adenophostin 2 (and therefore perhaps also of inositol adenophostin 4, if assumed to bind similarly in the nucleotide region) may be more restricted in its extended binding mode, influencing options available for the glucose or inositol bisphosphate components. By contrast, the simpler 4 could be more flexible and more able to optimize its fit in the likely more important region of $\operatorname{Ins}(1,4,5) \mathrm{P}_{3} \mathrm{R}$. Note also that when comparing ribophostin 6 with $\operatorname{Ins}(1,4,5) \mathrm{P}_{3} 1$ in activity, the former appears to be ca. 1.3- to 1.5 -fold more potent. The precise reasons why a ligand without an adenine base, but now based on an inositol-sugar polyphosphate hybrid rather than a sugar-sugar counterpart, should significantly exceed Ins$(1,4,5) \mathrm{P}_{3}$ in potency need further investigation. Since the conformation of disaccharides and a polyphosphate derivative such as $\mathbf{6}$ is mainly determined by the populations of rotamers around the glycosidic linkage, it could be pertinent to consider how changing this linkage to a sec-sec ether in 10 might change this. However, $\mathbf{1 0}$ appears to be the most potent simple (i.e., nondimeric and non-adenophostin A-based) smallmolecule $\mathrm{Ca}^{2+}$-mobilizing analogue yet synthesized. Also, its possession of an axial Ins $(1,4,5) \mathrm{P}_{3} 2$-hydroxyl mimic, in place of a pyranoside oxygen as in $\mathbf{4}$ affords the same extra synthetic flexibility for further structural elaboration that might allow access to the cleft of the $\operatorname{Ins}(1,4,5) \mathrm{P}_{3} \mathrm{R}$ clam by a suitably tailored pendant group.

We also compared the relative abilities of $\mathbf{1 0}$ and its nucleotide parent 4 in a functional sense to activate $\mathrm{I}_{\mathrm{CRAC}}$ in rat basophilic leukemia RBL-2H3 cells in comparison to Ins-
$(1,4,5) \mathrm{P}_{3}$ and adenophostin $\mathrm{A}$. We selected a concentration of $200 \mathrm{nM}$ for $\operatorname{Ins}(1,4,5) \mathrm{P}_{3}$ because this dose is just below the threshold for $\mathrm{I}_{\text {CRAC }}$ activation. ${ }^{47}$ Dialysis with $200 \mathrm{nM}$ adenophostin $\mathrm{A}$ evoked a large $\mathrm{I}_{\mathrm{CRAC}}$ after a short delay (Figure 11b), as reported previously. ${ }^{4,48}$ The current-voltage relationship, taken at steady state, is shown on the right and reveals the strong inward rectification and positive reversal potential that are hallmarks of $\mathrm{I}_{\mathrm{CRAC}}$. Current amplitude from several cells is shown in the plot in Figure 11e. Inositol adenophostin 4 activated $\mathrm{I}_{\mathrm{CRAC}}$ with similar kinetics to adenophostin $\mathrm{A}$, and the amplitude of the current (at -80 $\mathrm{mV}$ ) was similar to that evoked by adenophostin A (Figure 11a). Inositol ribophostin 4 also activated $I_{\text {CRAC }}$ but after a slightly longer delay, and the current typically attained a smaller amplitude (Figure 11d). We thus demonstrate for the first time that inositol adenophostin $\mathbf{4}$ is able to elicit a functional store-operated $\mathrm{Ca}^{2+}$ current $\mathrm{I}_{\mathrm{CRAC}}$ in patch-clamped cells, similar to adenophostin A 2 (Figure 11b), an activity downstream of the $\operatorname{Ins}(1,4,5) \mathrm{P}_{3} \mathrm{R}$, whereas $\operatorname{Ins}(1,4,5) \mathrm{P}_{3}$ itself (Figure 11d) is inactive. Inositol ribophostin 10 (Figure 11c) is also able to stimulate this current. As is apparent from Figure $11 \mathrm{e}$, inositol adenophostin is thus functionally similar to adenophostin and both are slightly more potent than inositol ribophostin. All three are considerably more potent than Ins $(1,4,5) \mathrm{P}_{3}$ under these conditions with its lack of activity presumably the result of extensive metabolism. This confirms not only the high activity of $\mathbf{1 0}$ but suggests it to be substantially hydrolysis-resistant in whole cells, potentially enhancing its value along with $\mathbf{4}$ as an investigative tool for chemical biology.

\section{CONCLUSIONS}

In summary, a concise first synthesis of D-chiro-inositol ribophostin 10, an inositol-based counterpart of the glyconucleotide natural product adenophostin analogue ribophostin has been achieved. Key features include coupling of a chiralprotected myo-inositol diol derivative activated as its triflate $\mathbf{1 1}$ to the chiral-protected ribose derivative 12. The chiral diol D(-)-1,2:4,5-di-O-isopropylidene-myo-inositol 22, ${ }^{36-38}$ derived from the separable diastereoisomeric 3-O-camphanate derivative of its 6-O-p-methyoxybenzyl ether, was used to define the absolute configuration of $\mathbf{1 1}$ by comparison with the literature values. Subsequent elaboration of the coupled product after deprotection of the labile isopropylidene group and monobenzylation of the stannylene-mediated vicinal hydroxyl group with separation and identification of regioisomers afforded a suitably protected triol $\mathbf{1 7}$. After phosphitylation and oxidation, the removal of all protecting groups afforded the target $\mathbf{1 0}$ that was evaluated as an agonist for intracellular $\mathrm{Ca}^{2+}$ release through the $\operatorname{Ins}(1,4,5) \mathrm{P}_{3} \mathrm{R}$ in permeabilized cells stably expressing $\operatorname{Ins}(1,4,5) \mathrm{P}_{3} \mathrm{R} 1$. D-chiro-Inositol ribophostin was more potent than $\operatorname{Ins}(1,4,5) \mathrm{P}_{3}$ and, more particularly, its disaccharide parent ribophostin surprisingly approached adenophostin A in activity, being only ca. 2-fold weaker. This was also confirmed using equilibrium-competition binding studies using displacement of $\left[{ }^{3} \mathrm{H}\right]-\operatorname{Ins}(1,4,5) \mathrm{P}_{3}$. Thus, glucopyranoside-inositol replacement can further optimize biological activity, presumably by facilitating a better fit to Ins $(1,4,5) \mathrm{P}_{3} \mathrm{R}$ than a pyranoside-based mimic directly based on the natural product adenophostin A. $\mathbf{1 0}$ is the most potent simple analogue agonist of $\operatorname{Ins}(1,4,5) \mathrm{P}_{3} \mathrm{R}$ so far identified that does not possess the adenine base motif of adenophostin $\mathrm{A}$ thought to enhance receptor binding. Moreover, using the 
patch-clamp methodology, 10 was shown to elicit a downstream store-operated $\mathrm{Ca}^{2+}$ current like adenophostin A, demonstrating both its efficacy and metabolic stability. Ins $(1,4,5) \mathrm{P}_{3}$ under the same conditions showed no response and is presumably heavily metabolized. This further underlines the potential of such ligands as chemical biology tools. Structure-activity implications are discussed in the context of Ins $(1,4,5) \mathrm{P}_{3}$, adenophostin $\mathrm{A}$, and ribophostin. D-chiro-Inositol ribophostin thus represents a new class of simple but highly potent Ins $(1,4,5) \mathrm{P}_{3}$ analogue as a phosphorylated inositolsugar conjugate that may be useful for further development and chemical biology applications.

\section{EXPERIMENTAL SECTION}

$\mathrm{Ca}^{2+}$-Release Assays. The methods used to measure $\mathrm{Ca}^{2+}$ release from the intracellular stores of permeabilized HEK or DT40 cells stably expressing only $\operatorname{Ins}(1,4,5) \mathrm{P}_{3} \mathrm{R} 1$ were exactly as reported previously. ${ }^{11,20}$ Briefly, stable cell lines expressing rat $\operatorname{Ins}(1,4,5) \mathrm{P}_{3} \mathrm{R} 1$ were established from cells in which all endogenous $\operatorname{Ins}(1,4,5) \mathrm{P}_{3} \mathrm{R}$ genes had been disrupted. The intracellular stores were loaded with a low-affinity fluorescent $\mathrm{Ca}^{2+}$ indicator (Mag-fluo4), the plasma membrane of the cells was then permeabilized by incubation with saponin, and the intracellular stores were loaded with $\mathrm{Ca}^{2+}$ by incubating cells in 96-well plates in a cytosol-like medium containing ATP. A FlexStation III plate-reader was used to record Mag-fluo4 fluorescence at $1.44 \mathrm{~s}$ intervals during $\mathrm{Ca}^{2+}$ loading and then in the presence of cyclopiazonic acid, to inhibit further $\mathrm{Ca}^{2+}$ uptake, added either with the Ins $(1,4,5) \mathrm{P}_{3} \mathrm{R}$ ligands (DT40 cells) or $60 \mathrm{~s}$ before addition of the ligands (HEK cells). $\mathrm{Ca}^{2+}$ release was calculated as a percentage of the fluorescence signal from fully loaded stores $\left(F_{\text {full }}\right)$ minus the signal from empty stores $\left(F_{\text {full }}-F_{\text {empty }}\right)$.

$\left[{ }^{3} \mathrm{H}\right]-\operatorname{Ins}(1,4,5) \mathrm{P}_{3}$ Binding Assays. Equilibrium competition binding to membranes prepared from rat cerebellum was performed in a medium comprising $50 \mathrm{mM}$ Tris, $1 \mathrm{mM}$ ethylenediaminetetraacetic acid (EDTA), pH 8.3 with $\left[{ }^{3} \mathrm{H}\right]-\operatorname{Ins}(1,4,5) \mathrm{P}_{3}(19.3 \mathrm{Ci} / \mathrm{mmol}$, $1.5 \mathrm{nM}$ ), and the competing ligand and evaluated exactly as reported previously. 39

Data Analysis. Concentration-effect relationships and equilibrium competition-binding results were fitted to Hill equations (GraphPad Prism, version 5), and $\mathrm{EC}_{50} / K_{\mathrm{d}}$ ratios were processed as previously described. ${ }^{39}$ Statistical analysis used analysis of variance (ANOVA) followed by Bonferroni's multiple comparison test (GraphPad Prism, version 5). $P<0.05$ was considered significant.

Electrophysiology. Patch clamp experiments were conducted on rat basophilic leukemia RBL-2H3 cells (ATCC CRL-2256) in the tight seal whole-cell configuration at room temperature $\left(20-24{ }^{\circ} \mathrm{C}\right)$ as previously described. ${ }^{47}$ Pipettes were pulled from borosilicate glass and then Sylgard-coated and fire-polished. They had resistances of 4$6 \mathrm{M} \Omega$ when filled with an internal solution containing $(\mathrm{mM}) 145 \mathrm{Cs}$ glutamate, $8 \mathrm{NaCl}, 1 \mathrm{MgCl}_{2}$, 10 HEPES, 0.35 EGTA, $2 \mathrm{Mg}$-ATP, $\mathrm{pH}$ $7.2(\mathrm{CsOH})$. The internal solution was supplemented with $200 \mathrm{nM}$ $\operatorname{Ins}(1,4,5) \mathrm{P}_{3}$, adenophostin $\mathrm{A}$, inositol adenophostin, or inositol ribophostin, as indicated. The external solution contained (mM) 155 $\mathrm{NaCl}, 10 \mathrm{CaCl}_{2}, 10 \mathrm{CsCl}, 2.8 \mathrm{KCl}, 2 \mathrm{MgCl}_{2}, 10$ HEPES, 10 glucose, $\mathrm{pH} 7.4(\mathrm{NaOH})$. Whole-cell currents were filtered using an eight-pole Bessel filter at $2.5 \mathrm{kHz}$ and digitized at $100 \mu \mathrm{s}$. The store-operated $\mathrm{Ca}^{2+}$ current $\mathrm{I}_{\text {CRAC }}$ was measured at $-80 \mathrm{mV}$ from voltage ramps spanning -100 to $+100 \mathrm{mV}$ ( $50 \mathrm{~ms}$ duration, $0.5 \mathrm{~Hz}, 0 \mathrm{mV}$ holding potential). Whole-cell currents were normalized to cell capacitance. Capacitative currents were automatically compensated for before each ramp by the EPC 9-2 amplifier (HEKA, Lambrecht/Pfalz, Germany). Leak currents were removed by subtracting the first one to five ramps obtained immediately after break-in.

Chemistry. Chemicals were purchased from Acros Organics, Alfa Aesar, Fisher Scientific, and Sigma-Aldrich. thin-layer chromatography (TLC) was carried out on Merck TLC aluminum sheets coated with silica $60 \mathrm{~F}_{254}$. The products were developed by dipping a TLC plate in an ethanolic solution of phosphomolybdic acid, and then heated at a high temperature. Flash chromatography was performed using silica 60 A (Fisher Scientific). Hexamethylphosphoramide (HMPA) was dried over calcium hydride and distilled under pressure. Organic solutions of compounds were dried over dry $\mathrm{MgSO}_{4}$. All compounds were characterized by spectroscopic methods (NMR and MS), and the final compound was purified using ion-exchange chromatography with a LKB-Pharmacia Medium Pressure Ion Exchange Chromatograph using Q-Sepharose Fast Flow and a $0-2.0 \mathrm{M}$ gradient of triethylammonium bicarbonate (TEAB) followed by purification over RP18 resin. Fractions containing the final compound were identified by the Briggs test, ${ }^{34}$ and compounds were then quantified by this assay, using a standard curve. Briefly, column fractions containing a polyphosphate were assayed for phosphate by a modification of the assay as follows: ${ }^{35}$ a molybdate solution $(12.5 \mathrm{~g}$ of ammonium molybdate dissolved in $250 \mathrm{~mL}$ of water and $35 \mathrm{~mL}$ of concentrated $\mathrm{H}_{2} \mathrm{SO}_{4}$ ), a hydroquinone solution ( $0.5 \mathrm{~g}$ of hydroquinone dissolved in $100 \mathrm{~mL}$ of water and a drop of concentrated $\mathrm{H}_{2} \mathrm{SO}_{4}$ ), and a sulfite solution $(20 \% \mathrm{w} / \mathrm{v}$ sodium sulfite in water) were prepared. Aliquots $(250 \mu \mathrm{L})$ of the fractions were transferred into test tubes, concentrated $\mathrm{H}_{2} \mathrm{SO}_{4}$ (three drops) was added, and the samples were heated at $150{ }^{\circ} \mathrm{C}$ for $1 \mathrm{~h}$. After cooling, water $(500 \mu \mathrm{L})$, molybdate solution $(500 \mu \mathrm{L})$, hydroquinone solution $(250 \mu \mathrm{L})$, and sulfite solution $(250 \mu \mathrm{L})$ were added and the samples were boiled for $7 \mathrm{~s}$ and allowed to cool. Phosphate-containing fractions were identified by their blue color. For quantitative analysis, samples containing known amounts of potassium dihydrogen phosphate were co-assayed with samples of unknown phosphate contents. After being processed as above, fractions were transferred to $10 \mathrm{~mL}$ volumetric flasks, water was added to give $10 \mathrm{~mL}$ of solution, and the UV absorbance at $340 \mathrm{~nm}$ was recorded using $3 \mathrm{~mL}$ quartz cells. The concentration of the unknown samples was calculated from a standard curve derived from the absorbances of the reference samples. Final compounds were used in biological assays after such quantification as their triethylammonium salts. All compounds were of purity $>95 \%$ by NMR. ${ }^{1} \mathrm{H}$ NMR spectra were recorded at $400 \mathrm{MHz}$ and $500 \mathrm{MHz}$, ${ }^{13} \mathrm{C}$ NMR spectra were recorded at $100 \mathrm{MHz}$ and $125 \mathrm{MHz}$, and ${ }^{31} \mathrm{P}$ spectra at $202.4 \mathrm{MHz}$ on a Varian Mercury VX400 NMR machine and a $500 \mathrm{MHz}$ Bruker Advance III. Mass spectra were recorded on a Bruker MicrOTOF electrospray electrospray ionization time-of-flight (ESI-TOF) spectrometer with sodium formate as the standard. Melting points were recorded on a Systems Optimelt automated melting point system. Optical rotations were measured in an Optical Activity Ltd AA-10 polarimeter.

(3aS,4S,4aS,7a $R, 8 R, 8 \mathrm{a} S)-4-(((3 R, 4 R, 5 R)-2-(($ Benzyloxy)methyl)-5-methoxy-4-((4-methoxybenzyl) oxy $)$ tetrahydrofuran-3-yl)oxy)-8-((4-methoxybenzyl)oxy)-2,2,6,6tetramethylhexahydrobenzo $\left[1,2-d: 4,5-d^{\prime}\right]$ bis ([1,3]dioxole) (13). Dry HMPA (2 mL) was added to methyl 5-O-benzyl-2-O-pmethoxybenzyl- $\beta$-D-ribofuranoside $(12,200 \mathrm{mg}, 0.53 \mathrm{mmol})$ and $\mathrm{NaH}$ (25 mg, 95\%, $1.0 \mathrm{mmol}$ ), and the mixture was stirred under argon for $30 \mathrm{~min}$ and cooled with ice. L-(+)-1,2:4,5-di-Oisopropylidene-6-O-p-methoxybenzyl-3-O-trifluoromethanesulfonylmyo-inositol (11, $555 \mathrm{mg}, 1.07 \mathrm{mmol})$ was added as a solid, and the remainder in the weighing vessel was washed with dry THF $(2 \mathrm{~mL})$. The reaction mixture turned orange/yellow, and the reaction was allowed to warm to room temperature as the ice melted. The reaction was allowed to slowly warm to lab temperature after the addition of the triflate, and the mixture was stirred overnight, for $17 \mathrm{~h}$ in total.

The THF was evaporated and the solution of HMPA was poured into a saturated solution of ammonium chloride $(25 \mathrm{~mL})$, and the solution was left to separate. The liquid part was decanted off, and this contained mainly the HMPA with a trace amount of product and starting material. The remaining solid products were extracted with ether $(4 \times 25 \mathrm{~mL})$ after a further addition of saturated ammonium chloride $(25 \mathrm{~mL})$. Purification by chromatography $40-60{ }^{\circ} \mathrm{C}$ petroleum ether/EtOAc $(2: 1)$ provides the product $(13,241 \mathrm{mg}$, $62 \%) .[\alpha]_{\mathrm{D}}=+33.33^{\circ}, 20^{\circ} \mathrm{C},\left(c=1.74, \mathrm{CHCl}_{3}\right)$.

${ }^{1} \mathrm{H}$ NMR $\left(500 \mathrm{MHz}, \mathrm{CDCl}_{3}\right) 1.24,1.31,1.33,1.42(12 \mathrm{H}, 4 \mathrm{~s}, 4 \times$ $\left.\mathrm{CH}_{3}\right), 3.29(3 \mathrm{H}$, s, ribose-OMe $), 3.57-3.63\left(3 \mathrm{H}, \mathrm{m}, \mathrm{CH}_{2} \mathrm{OBn}, 1 \mathrm{H}\right.$, H-4-Ins), $3.73(1 \mathrm{H}, \mathrm{dd}, J=2.6,10.0 \mathrm{~Hz}, \mathrm{H}-2-\operatorname{Ins}), 3.76(3 \mathrm{H}, \mathrm{s}$, 
$\mathrm{CH}_{2} \mathrm{PhOMe}$ ), 3.80 ( $\left.3 \mathrm{H}, \mathrm{s}, \mathrm{CH}_{2} \mathrm{PhOMe}\right), 3.88(1 \mathrm{H}, \mathrm{d}, J=4.5 \mathrm{~Hz}, \mathrm{H}-$ 2-ribose), $4.02(1 \mathrm{H}, \mathrm{t}, J=10.0 \mathrm{~Hz}, \mathrm{H}-3$-Ins $), 4.19-4.25(2 \mathrm{H}, \mathrm{m}, \mathrm{H}-$ 4-ribose, H-4-Ins), 4.32-4.35 (2 H, m, H-1-Ins, H-6-Ins), 4.39 (1 H, dd, $J=4.5,7.2 \mathrm{~Hz}, \mathrm{H}-3$-ribose $)$, 4.57-4.75 $\left(6 \mathrm{H}, \mathrm{m}, \mathrm{CH}_{2} \mathrm{Ph}\right.$, $\mathrm{CH}_{2} \mathrm{PhOMe}$ ), 4.81 (1 H, s, H-1-ribose), 6.84-6.88 (4 H, m, $2 \times$ $\mathrm{CH}_{2} \mathrm{PhOMe}$ ), $7.25-7.36$ ( $\left.9 \mathrm{H}, \mathrm{m}, \mathrm{CH}_{2} \mathrm{Ph}, \mathrm{CH}_{2} \mathrm{PhOMe}\right)$.

${ }^{13} \mathrm{C}$ NMR $\left(125 \mathrm{MHz}, \mathrm{CDCl}_{3}\right)$ 25.73, 26.79, 27.20, 27.70 (4 q, $2 \times$ $\left.\mathrm{C}\left(\mathrm{CH}_{3}\right)_{2}\right), 54.89,56.24,56.25\left(3 \mathrm{q}, 2 \times \mathrm{CH}_{2} \mathrm{PhOMe}\right.$, ribose-OMe), 70.88, 71.46, 72.19, 73.37 (4 t, $\mathrm{CH}_{2} \mathrm{Ph}, \mathrm{CH}_{2} \mathrm{PhOMe}, \mathrm{CH}_{2} \mathrm{OBn}$ ), $72.80,75.20,76.69,77.90,79.78,80.12,80.37,80.51,81.76,106.20$ $(10 \times-\mathrm{C}-\mathrm{H}$ ring carbons for inositol and ribose $), 109.25,111.19\left(C_{\mathrm{q}}\right.$, $\left.2 \times C(\mathrm{Me})_{2}\right), 113.53,113.81\left(\mathrm{C}-\mathrm{H}, 2 \times \mathrm{CH}_{2} \mathrm{PhOMe}\right), 127.53$, 128.32, 129.27, 129.50 (d, C-H, $\mathrm{CH}_{2} P h, \mathrm{CH}_{2} \mathrm{PhOMe}$ ), 130.22, 130.59, $138.07\left(C_{q}, \mathrm{~s}, \mathrm{CH}_{2} P h, \mathrm{CH}_{2} P h \mathrm{OMe}\right), 159.01,159.21$ ( $C_{q}, \mathrm{~s}$, $\left.\mathrm{CH}_{2} \mathrm{PhOMe}\right) . M / z \mathrm{C}_{41} \mathrm{H}_{53} \mathrm{O}_{12}[\mathrm{M}+\mathrm{H}]^{+}$expected 737.3532; found 737.3532: $\mathrm{C}_{41} \mathrm{H}_{52} \mathrm{NaO}_{12}[\mathrm{M}+\mathrm{Na}]^{+}$expected 759.3351; found 759.3340 .

(3aS,4R,5R,6R,7S,7aR)-4-(((3R,4R,5R)-2-((Benzyloxy)methyl)5-methoxy-4-((4-methoxybenzyl)oxy)tetrahydrofuran-3-yl)ox y ) - 7 - ( ( 4 - m e t h ox y b e nzy I) oxy ) - 2, 2 dimethylhexahydrobenzo[d][1,3]dioxole-5,6-diol (14). The fully blocked compound $(13,381 \mathrm{mg}, 517 \mu$ moles) was dissolved in methylene chloride $(25 \mathrm{~mL})$ followed by the addition of a catalytic amount of PTSA (5 mg, $0.025 \mathrm{mmol})$ and ethane 1,2-diol $(38 \mathrm{mg}$, $0.612 \mathrm{mmol}), 1.18$ equiv. The mixture was stirred at room temperature, and the reaction was complete within 10-15 min and monitored by TLC [EtOAc/petroleum ether $(2: 1)], R_{\mathrm{f}}=0.44$ for the diastereoisomer 14. The product was purified by flash chromatography using a combiflash and gradient of EtOAc/petroleum ether 2:1. Yield $306 \mathrm{mg}, 85 \% .[\alpha]_{\mathrm{D}} 23{ }^{\circ} \mathrm{C}=+63.2^{\circ},\left(c=2.5, \mathrm{CHCl}_{3}\right)$.

${ }^{1} \mathrm{H}$ NMR (500 MHz, Me $\left.\mathrm{SO}\right) 1.20,1.32\left(6 \mathrm{H}, 2 \mathrm{~s}, \mathrm{C}\left(\mathrm{CH}_{3}\right)_{2}\right), 3.21$ ( $3 \mathrm{H}$, s, ribose-OMe), $3.26(1 \mathrm{H}, \mathrm{dd}, J=7.2,8.6 \mathrm{~Hz}, \mathrm{H}-\mathrm{Ins}), 3.46-$ $3.58\left(3 \mathrm{H}, \mathrm{m}, \mathrm{CH}_{2} \mathrm{OBn}, \mathrm{H}-5\right.$-ribose, $\mathrm{H}-2$ or H-3-Ins), 3.66 ( $1 \mathrm{H}, \mathrm{dt}, J$ $=2.2,4.7 \mathrm{~Hz}, \mathrm{H}-2$ or H-3-Ins, $\mathrm{D}_{2} \mathrm{O}$ exch.), 3.73, 3,73 (6 H, $2 \mathrm{~s}$, $\mathrm{CH}_{2} \mathrm{PhOMe}$ ), 3.77 ( $\left.1 \mathrm{H}, \mathrm{dd}, J=2.1,5.1 \mathrm{~Hz}, \mathrm{H}-\mathrm{Ins}\right), 3.87(1 \mathrm{H}, \mathrm{d}, J=$ $4.7 \mathrm{~Hz}, \mathrm{H}-2$-ribose), 4.02 ( $1 \mathrm{H}, \mathrm{m}, \mathrm{H}-4$-ribose $), 4.13(1 \mathrm{H}, \mathrm{dd}, J=6.8$, $8.5 \mathrm{~Hz}, \mathrm{H}-\mathrm{Ins}), 4.20-4.25$ ( $2 \mathrm{H}, \mathrm{m}, \mathrm{H}-\mathrm{Ins}$ and H-ribose), 4.51-4.67 $\left(6 \mathrm{H}, \mathrm{m}, \mathrm{CH}_{2} \mathrm{Ph}, 2 \times \mathrm{CH}_{2} \mathrm{PhOMe}\right), 4.85$ (1 H, s, H-1-ribose), 4.97 (1 $\mathrm{H}, \mathrm{d}, J=4.7 \mathrm{~Hz}, \mathrm{D}_{2} \mathrm{O}$ exch., Ins-OH), $5.15\left(1 \mathrm{H}, \mathrm{d}, J=5.1 \mathrm{~Hz}, \mathrm{D}_{2} \mathrm{O}\right.$ exch., Ins-OH), 6.87-6.89 (4 H, m, $\left.2 \times \mathrm{CH}_{2} P h \mathrm{OMe}\right), 7.24-7.32$ (9 $\left.\mathrm{H}, \mathrm{m}, \mathrm{CH}_{2} \mathrm{Ph}, 2 \times \mathrm{CH}_{2} \mathrm{PhOMe}\right)$.

${ }^{13} \mathrm{C} \mathrm{NMR}\left(125 \mathrm{MHz}, \mathrm{Me}_{2} \mathrm{SO}\right) 25.47,27.71\left(2 \mathrm{q}, \mathrm{C}\left(\mathrm{CH}_{3}\right)_{2}\right), 54.28$, 55.02, 55.02 ( $3 \mathrm{q}, 2 \times \mathrm{CH}_{2} \mathrm{PhOMe}$, ribose-OMe), 71.14, 71.16, 71.71, 72.19 ( 4 t, $\mathrm{CH}_{2} \mathrm{Ph}, \mathrm{CH}_{2} \mathrm{PhOMe}, \mathrm{CH}_{2} \mathrm{OBn}$ ), 73.08, 74.04, 76.74, 77.85 ( 2 carbon signals), 78.38, 79.07, 80.04, 83.52, 105.74 (10 $\times-C-\mathrm{H}$ ring carbons for inositol and ribose), $108.31\left(C_{q}, C(\mathrm{Me})_{2}\right), 113.37,113.59$ (C-H, $2 \times \mathrm{CH}_{2} \mathrm{PhOMe}$ ), 127.28 (2 carbon signals), 127.32, 128.17, 129.00, 129.72 (d, C-H, $\mathrm{CH}_{2} \mathrm{Ph}, \mathrm{CH}_{2} \mathrm{PhOMe}$ ), 129.95, 130.98, $138.39\left(C_{\mathrm{q}}, \mathrm{s}, \mathrm{CH}_{2} \mathrm{Ph}, \mathrm{CH}_{2} \mathrm{PhOMe}\right), 158.47,158.47\left(\mathrm{C}_{\mathrm{q}}, \mathrm{s}\right.$, $\mathrm{CH}_{2} \mathrm{PhOMe}$ ).

$M / z \mathrm{C}_{38} \mathrm{H}_{48} \mathrm{NaO}_{12}[\mathrm{M}+\mathrm{Na}]^{+}$expected 719.3038; found 719.3009.

(3aS,4R,5R,6R,7S,7a R)-6-(Benzyloxy)-4-(((3R,4R,5R)-2((Benzyloxy)methyl)-5-methoxy-4-((4-methoxybenzyl)oxy)tetrahydrofuran-3-yl)oxy)-7-((4-methoxybenzyl)oxy)-2,2dimethylhexahydrobenzo[ $[d][1,3]$ dioxol-5-ol (15) and (3a $R, 4 S, 5 R, 6 R, 7 R, 7 \mathrm{a} S)-6$-(Benzyloxy)-7-(((3R,4R,5R)-2((Benzyloxy)methyl)-5-methoxy-4-((4-methoxybenzyl)oxy)tetrahydrofuran-3-yl)oxy)-4-((4-methoxybenzyl)oxy)-2,2dimethylhexahydrobenzo[d][1,3]dioxol-5-ol (16). The diol (14, $419 \mathrm{mg}, 0.60 \mathrm{mmol})$ and dibutyltin oxide $(180 \mathrm{mg}, 0.72 \mathrm{mmol})$ in toluene $(100 \mathrm{~mL})$ were heated at reflux temperature overnight for 18 $\mathrm{h}$ with the Dean-Stark apparatus with the removal of water. The reaction mixture was cooled and the solvents were evaporated off to give a glassy residue, which was dried overnight. Cesium fluoride (327 $\mathrm{mg}, 2.16 \mathrm{mmol})$, dry dimethylformamide (DMF) $(10 \mathrm{~mL})$, and benzyl bromide $(240 \mu \mathrm{L}, 2.0 \mathrm{mmol})$ were added to the mixture, which was stirred overnight $(18 \mathrm{~h})$. TLC (EtOAc/petrol, 1:1) showed two products $R_{\mathrm{f}}=0.50$ and $R_{\mathrm{f}}=0.42$. The solvents were evaporated under reduced pressure, the residue was partitioned between EtOAc and water $(20 \mathrm{~mL}$ of each), and the organic phase was stirred with sodium hydrogen carbonate solution $(20 \mathrm{~mL})$ for $30 \mathrm{~min}$. The resulting milky organic layer was filtered over a bed of celite, dried, and the solvent was evaporated. The resulting residue was purified by flash chromatography (EtOAc/petroleum ether, 2:3) to give the title compound as a glass (122 mg, 30.5\%) (of consumed compound), (upper spot) together with the lower $R_{\mathrm{f}}$ product $(124 \mathrm{mg}, 31 \%)$ and $66 \mathrm{mg}$ of starting material, thus $353 \mathrm{mg}$ is used up. Yields were based upon the benzylated compound.

3-O-Benzyl Diastereoisomer (15). ${ }^{1} \mathrm{H}$ NMR (400 MHz, $\left.\mathrm{CD}_{3} \mathrm{CN}\right) 1.35,1.47\left(6 \mathrm{H}, 2 \mathrm{~s}, \mathrm{C}\left(\mathrm{CH}_{3}\right)_{2}\right), 3.28(3 \mathrm{H}, \mathrm{s}$, ribose$\mathrm{OMe}$ ), 3.49-3.55 (2 H, m, H-Ins), 3.60-3.71 ( $3 \mathrm{H}, \mathrm{m},-\mathrm{CH}_{2} \mathrm{OBn}, \mathrm{H}-$ Ins), 3,79, $3.84\left(6 \mathrm{H}, 2 \mathrm{~s}, 2 \times \mathrm{CH}_{2} \mathrm{PhOMe}\right), 3.87-3.92(2 \mathrm{H}, \mathrm{m}, 2 \times$ H-Ins), 4.00 ( $1 \mathrm{H}, \mathrm{dd}, J=1.3,4.9 \mathrm{~Hz}, \mathrm{H}-2$-ribose), 4.15 ( $1 \mathrm{H}, \mathrm{ddd}, J=$ $3.9,5.8,6.8 \mathrm{~Hz}, \mathrm{H}-4$-ribose), 4.22 ( $1 \mathrm{H}, \mathrm{m}, \mathrm{H}-\mathrm{Ins}), 4.28$ ( $1 \mathrm{H}, \mathrm{dd}, J=$ $4.8,6.7 \mathrm{~Hz}, \mathrm{H}-3$-ribose ), $4.33(1 \mathrm{H}, \mathrm{dd}, J=4.7,6.5 \mathrm{~Hz}, \mathrm{H}-\mathrm{Ins}), 4.58-$ $4.78\left(8 \mathrm{H}, \mathrm{CH}_{2} \mathrm{Ph}, \mathrm{CH}_{2} \mathrm{PhOMe}\right), 5.05(1 \mathrm{H}, \mathrm{d}, J=1.2 \mathrm{~Hz}, \mathrm{H}-1-$ ribose), $6.92\left(2 \mathrm{H}, \mathrm{d}, J=8.9 \mathrm{~Hz}, \mathrm{CH}_{2} P h \mathrm{OMe}\right), 6.93(2 \mathrm{H}, \mathrm{d}, J=8.9$ $\left.\mathrm{Hz}, \mathrm{CH}_{2} \mathrm{PhOMe}\right), 7.32\left(2 \mathrm{H}, \mathrm{d}, J=8.9 \mathrm{~Hz}, \mathrm{CH}_{2} \mathrm{PhOMe}\right), 7.34-7.43$ $\left(12 \mathrm{H}, \mathrm{m}, 2 \times \mathrm{CH}_{2} \mathrm{Ph}, \mathrm{CH}_{2} \mathrm{PhOMe}\right)$.

${ }^{13} \mathrm{C}$ NMR (100 MHz, $\left.\mathrm{CD}_{3} \mathrm{CN}\right) 25.96,28.17\left(2 \mathrm{q}, \mathrm{C}\left(\mathrm{CH}_{3}\right)_{2}\right), 55.39$ ( 2 carbon signals), 55.83 ( $3 \mathrm{q}, 2 \times \mathrm{CH}_{2} \mathrm{PhOMe}$, ribose-OMe), 72.41, 72.46, 73.73, 73.77, 74.11 (5t, $\mathrm{CH}_{2} \mathrm{Ph}, \mathrm{CH}_{2} \mathrm{PhOMe}, \mathrm{CH}_{2} \mathrm{OBn}$ ), 72.23, 76.61, 79.44, 79.68, 79.90, 80.57, 81.73, 82.78, 83.14, $106.95(10 \times$ $-\mathrm{C}$ - $\mathrm{H}$ ring carbons for inositol and ribose $), 110.08\left(\mathrm{C}_{\mathrm{q}}, \mathrm{C}(\mathrm{Me})_{2}\right)$, $114.44,114.70\left(\mathrm{C}-\mathrm{H}, 2 \times \mathrm{CH}_{2} \mathrm{PhOMe}\right), 128.37,128.47,128.58$, $128.81,129.15,129.30,130.40,131.05$ (d, C-H, $\mathrm{CH}_{2} \mathrm{Ph}$, $\left.\mathrm{CH}_{2} \mathrm{PhOMe}\right), 130.50,132.08,139.63,140.00\left(\mathrm{C}_{q}, \mathrm{~s}, \mathrm{CH}_{2} \mathrm{Ph}\right.$, $\left.\mathrm{CH}_{2} \mathrm{PhOMe}\right), 160.09,160.48\left(\mathrm{C}_{\mathrm{q}}, \mathrm{s}, \mathrm{CH}_{2} \mathrm{PhOMe}\right) . \mathrm{M} / z$ $\mathrm{C}_{45} \mathrm{H}_{54} \mathrm{NaO}_{12}[\mathrm{M}+\mathrm{Na}]^{+}$expected 809.3507; found 809.3534. 3-OBenzyl diastereoisomer: $[\alpha]_{\mathrm{D}} 20^{\circ} \mathrm{C}=+61.8^{\circ},\left(c=2.48, \mathrm{CHCl}_{3}\right)$.

2-O-Benzyl Derivative (16). ${ }^{1} \mathrm{H}$ NMR $\left(500 \mathrm{MHz}, \mathrm{CDCl}_{3}\right)$ 1.28, $1.43\left(6 \mathrm{H}, 2 \mathrm{~s}, \mathrm{C}\left(\mathrm{CH}_{3}\right)_{2}\right), 3.28(3 \mathrm{H}$, s, ribose-OMe $), 3.40(1 \mathrm{H}, \mathrm{dd}, J$ $=6.9,8.9 \mathrm{~Hz}, \mathrm{H}-4-\mathrm{Ins}), 3.56\left(2 \mathrm{H}, \mathrm{d}, J=5.0 \mathrm{~Hz},-\mathrm{CH}_{2} \mathrm{OBn}\right), 3.62(1$ $\mathrm{H}, \mathrm{dd}, J=2.6,8.0 \mathrm{~Hz}, \mathrm{H}-2-$ Ins $), 3.73,3.79(6 \mathrm{H}, 2 \mathrm{~s}, 2 \times$ $\mathrm{CH}_{2} \mathrm{PhOMe}$ ), $3.85(1 \mathrm{H}, \mathrm{dd}, J=1.3,8.3 \mathrm{~Hz}, \mathrm{H}$-2-ribose), $3.98(1 \mathrm{H}$, $\mathrm{dt}, J=1.8,8.3 \mathrm{~Hz}, \mathrm{H}-3-\mathrm{Ins}), 4.08$ ( $1 \mathrm{H}, \mathrm{t}, J=3.2 \mathrm{~Hz}, \mathrm{H}-1-\mathrm{Ins})$, 4.194.22 ( $1 \mathrm{H}, \mathrm{m}, \mathrm{H}-4$-ribose), 4.24-4.31 (3 H, m, H-3-ribose, H-6-Ins, H-5-Ins), 4.44-4.85 ( $\left.8 \mathrm{H}, \mathrm{m}, 2 \times \mathrm{CH}_{2} \mathrm{Ph}, 2 \times \mathrm{CH}_{2} \mathrm{PhOMe}\right), 4.77$ (1 $\mathrm{H}, \mathrm{d}, J=1.3 \mathrm{~Hz}), 6.76\left(2 \mathrm{H}, \mathrm{d}, J=8.7 \mathrm{~Hz}, \mathrm{CH}_{2} \mathrm{PhOMe}\right), 6.86(2 \mathrm{H}, \mathrm{d}$, $\left.J=8.7 \mathrm{~Hz}, \mathrm{CH}_{2} P h \mathrm{OMe}\right), 7.15\left(2 \mathrm{H}, \mathrm{d}, J=8.9 \mathrm{~Hz}, \mathrm{CH}_{2} P h \mathrm{OMe}\right)$, 7.25-7.32 (12 H, m, $\left.2 \times \mathrm{CH}_{2} P h, \mathrm{CH}_{2} P h \mathrm{OMe}\right)$.

${ }^{13} \mathrm{C}$ NMR (125 MHz, $\left.\mathrm{CDCl}_{3}\right)$ 25.92, $27.93\left(2 \mathrm{q}, \mathrm{C}\left(\mathrm{CH}_{3}\right)_{2}\right)$, 55.13, 55.20, 55.25 ( $3 \mathrm{q}, 2 \times \mathrm{CH}_{2} \mathrm{PhOMe}$, ribose-OMe), 71.06, 72.12, 72.75, 72.20, 73.32 (5t, $\mathrm{CH}_{2} \mathrm{Ph}, \mathrm{CH}_{2} \mathrm{PhOMe}, \mathrm{CH}_{2} \mathrm{OBn}$ ), 71.47, 76.05, 76.56, $79.02,79.94,80.27,80.45,80.91,83.41,106.47(10 \times-C-\mathrm{H}$ ring carbons for inositol and ribose), $109.39\left(\mathrm{C}_{\mathrm{q}}, \mathrm{C}(\mathrm{Me})_{2}\right), 113.68,113.74$ $\left(\mathrm{C}-\mathrm{H}, 2 \times \mathrm{CH}_{2} \mathrm{PhOMe}\right), 127.54,127.55,127.66,127.86,128.34$, $128.35,129.53,129.55$ (d, $\mathrm{C}-\mathrm{H}, \mathrm{CH}_{2} \mathrm{Ph}, \mathrm{CH}_{2} \mathrm{PhOMe}$ ), 130.11, 130.75, 138.10, 138.16 ( $\mathrm{C}_{\mathrm{q}}, \mathrm{s}, \mathrm{CH}_{2} \mathrm{Ph}, \mathrm{CH}_{2} \mathrm{PhOMe}$ ), 159.12, 159.15 $\left(C_{q}, \quad s, \mathrm{CH}_{2} \mathrm{PhOMe}\right) . \mathrm{M} / z \quad \mathrm{C}_{45} \mathrm{H}_{54} \mathrm{NaO}_{12}[\mathrm{M}+\mathrm{Na}]^{+}$expected 809.3507; found 809.3526. 2-O-Benzyl diastereoisomer: $[\alpha]_{\mathrm{D}} 20^{\circ} \mathrm{C}=$ $+19.1^{\circ},\left(c=2.44, \mathrm{CHCl}_{3}\right)$.

( $3 \mathrm{a} R, 4 S, 5 S, 6 R, 7 R, 7 \mathrm{a} S)-6$-(Benzyloxy)-7-(((3S,4R,5R)-2((benzyloxy)methyl)-4-hydroxy-5-methoxytetrahydrofuran-3yl)oxy)-2,2-dimethylhexahydrobenzo[d][1,3]dioxole-4,5-diol (17). A mixture of the 2-O-benzyl derivative $(16,184 \mathrm{mg}, 0.234$ $\mathrm{mmol})$ and DDQ $(188 \mathrm{mg}, 0.825 \mathrm{mmol})$ was stirred in dichloromethane $(9.5 \mathrm{~mL})$ and water $(0.5 \mathrm{~mL})$ for $1 \mathrm{~h}$ after which a salmoncolored precipitate was observed. The reaction was diluted with dichloromethane $(40 \mathrm{~mL})$, and the precipitate was filtered off and washed with $10 \%$ sodium sulfite solution $(2 \times 20 \mathrm{~mL})$, then washed with sodium hydrogen carbonate solution $(20 \mathrm{~mL})$ and water $(20$ $\mathrm{mL}$ ), dried, filtered, and the dichloromethane was evaporated to give an oil. The oily residue was chromatographed on silica gel using a gradient of petrol to $70 \%$ ethyl acetate to give the title compound 17; yield $(80 \mathrm{mg}, 63 \%) ; R_{\mathrm{f}}=0.42$ (ethyl acetate).

${ }^{1} \mathrm{H}$ NMR $\left(500 \mathrm{MHz}, \mathrm{CDCl}_{3}\right) 1.251 .43\left(6 \mathrm{H}, 2 \mathrm{~s}, \mathrm{C}\left(\mathrm{CH}_{3}\right)_{2}\right), 2.66$ $\left(1 \mathrm{H}, \mathrm{d}, J=3.4 \mathrm{~Hz}, \mathrm{D}_{2} \mathrm{O}\right.$, exch. Ins-3-OH $), 2.88(1 \mathrm{H}, \mathrm{d}, J=4.5 \mathrm{~Hz}$, $\mathrm{D}_{2} \mathrm{O}$, exch. Ins-4-OH), $3.32(3 \mathrm{H}, \mathrm{s}$, ribose-OMe $), 3.51-3.63(4 \mathrm{H}, \mathrm{m}$, $\mathrm{CH}_{2} \mathrm{OBn}, \mathrm{H}-5$-ribose, $\mathrm{H}-2$ or H-3-Ins), $3.86(1 \mathrm{H}, \mathrm{t}, J=2.9 \mathrm{~Hz}, \mathrm{H}-1$ or H-6-Ins), $3.89\left(1 \mathrm{H}, \mathrm{dt}, J=3.1,8.8 \mathrm{~Hz}, \mathrm{D}_{2} \mathrm{O}\right.$ exch. $J=8.8 \mathrm{~Hz}, \mathrm{H}-3-$ 
Ins), 4.02-4.04 (2 H, m, Ins and/or H-ribose), 4.10-4.16 (3 H, HIns and/or H-ribose, ribose-2- $\mathrm{OH}, \mathrm{D}_{2} \mathrm{O}$ exch. $), 4.18(1 \mathrm{H}, \mathrm{dd}, J=2.8$, $5.4 \mathrm{~Hz}, \mathrm{H}$-Ins or H-ribose), 7.26-7.38 $\left(10 \mathrm{H}, \mathrm{m}, 2 \times \mathrm{CH}_{2} \mathrm{Ph}\right)$.

${ }^{13} \mathrm{C}$ NMR (125 MHz, $\left.\mathrm{CDCl}_{3}\right)$ 25.72, $27.83\left(2 \mathrm{q}, \mathrm{C}\left(\mathrm{CH}_{3}\right)_{2}\right), 54.92$ (ribose- $\mathrm{OMe}$ ), 71.81, 73.45, 74.10 (3t, $\mathrm{CH}_{2} \mathrm{Ph}, \mathrm{CH}_{2} \mathrm{OBn}$ ), 71.81, $72.51,74.37,75.77,76.11,78.39$ (2 carbon signals), 79.20, 81.35, $108.01(10 \times-\mathrm{C}-\mathrm{H}$ ring carbons for inositol and ribose $), 110.89\left(C_{\mathrm{q}}\right.$, $\left.\mathrm{C}(\mathrm{Me})_{2}\right), 127.61,127.72,128.42,128.71$ (d, $\left.\mathrm{C}-\mathrm{H}, \mathrm{CH}_{2} \mathrm{Ph}\right), 136.83$, $137.90\left(C_{q}, \mathrm{~s}, \mathrm{CH}_{2} \mathrm{Ph}\right) . \mathrm{M} / z \mathrm{C}_{29} \mathrm{H}_{38} \mathrm{NaO}_{10}[\mathrm{M}+\mathrm{Na}]^{+}$expected 569.2357; found 569.2366. $[\alpha]_{\mathrm{D}} 22{ }^{\circ} \mathrm{C}=+23.5^{\circ},\left(c=1.1, \mathrm{CHCl}_{3}\right)$.

Tetrabenzyl ((3aS,4R,6S,7R,7aS)-6-(Benzyloxy)-7(( $(3 R, 4 R, 5 R)$-2-((benzyloxy)methyl)-4-((bis (benzyloxy)phosphoryl)oxy)-5-methoxytetrahydrofuran-3-yl)oxy)-2,2dimethylhexahydrobenzo[ $[d][1,3]$ dioxole-4,5-diyl) Bis(phosphate) (19). A mixture of bis(benzyloxy)diisopropylaminophosphine $(0.345 \mathrm{~g}, 1 \mathrm{mmol})$ and $1 H$-tetrazole $(0.21 \mathrm{~g}, 3 \mathrm{mmol})$ in dry $\mathrm{CDCl}_{3}(3 \mathrm{~mL})$ was stirred for $15 \mathrm{~min}$ at room temperature. The phosphitylating complex was added to the triol (17, $65 \mathrm{mg}, 0.119 \mathrm{mmol})$ in $\mathrm{CDCl}_{3}(2 \mathrm{~mL})$ and stirred for $30 \mathrm{~min}$ to give the P(III) intermediate (18). Solid $m$ CPBA $(345 \mathrm{mg}, 2.0 \mathrm{mmol}$ ) was added to the cooled solution using a dry ice-acetone bath, and the $\mathrm{P}(\mathrm{III})$ intermediate was oxidized and stirred for a further $30 \mathrm{~min}$. The solution was diluted with EtOAc $(20 \mathrm{~mL})$ and washed with $10 \%$ aqueous sodium sulfite solution $(2 \times 20 \mathrm{~mL})$. The organic layer was dried $\left(\mathrm{MgSO}_{4}\right)$, and the product was purified by flash chromatography using a gradient of petroleum ether ethyl acetate 100\% petroleum ether to (EtOAc/petroleum ether, 2:1), to give the trisphosphate $(19,114 \mathrm{mg}, 72 \%)$.

${ }^{1} \mathrm{H}$ NMR (500 MHz, $\left.\mathrm{CD}_{3} \mathrm{CN}\right) 1.251 .43\left(6 \mathrm{H}, 2 \mathrm{~s}, \mathrm{C}\left(\mathrm{CH}_{3}\right)_{2}\right)$, $3.55-3.69(2 \mathrm{H}, \mathrm{ABX}, J=10.7,3.5,5.4 \mathrm{~Hz}, \mathrm{H}-5$-ribose $), 4.10-4.13$ ( $1 \mathrm{H}, \mathrm{m}$, obscured, H-4-ribose), $4.14(1 \mathrm{H}, \mathrm{dd}, J=2.4,6.5 \mathrm{~Hz}, \mathrm{H}-\mathrm{Ins})$, $4.24(1 \mathrm{H}, \mathrm{t}, J=2.2 \mathrm{~Hz}, \mathrm{H}-1-\operatorname{Ins}), 4.38(1 \mathrm{H}, \mathrm{dd}, J=6.9,9.35 \mathrm{~Hz}, \mathrm{H}-$ Ins), $4.46(1 \mathrm{H}, \mathrm{t}, J=6.5 \mathrm{~Hz}, \mathrm{H}$-Ins or H-ribose $), 4.46(1 \mathrm{H}, \mathrm{dd}, J=$ 2.1, 7.3 Hz, H-Ins or H-ribose), 4.53-4.69 (7 H, m, H-2-ribose, H-3Ins, H-4-Ins, $\left.2 \times \mathrm{CH}_{2} \mathrm{Ph}\right), 4.83(1 \mathrm{H}, \mathrm{s}, \mathrm{H}-1$-ribose $), 4.96-5.10$ (12 $\left.\mathrm{H}, 3 \times \mathrm{P}(\mathrm{O}) \mathrm{O}\left(\mathrm{CH}_{2} \mathrm{Ph}\right)_{2}\right), 7.23-7.37\left(40 \mathrm{H}, 3 \times \mathrm{P}(\mathrm{O}) \mathrm{O}\left(\mathrm{CH}_{2} \mathrm{Ph}\right)_{2}, 2\right.$ $\left.\times \mathrm{CH}_{2} \mathrm{Ph}\right) .{ }^{31} \mathrm{P}$ NMR $\left(202.4 \mathrm{MHz}, \mathrm{CD}_{3} \mathrm{CN}\right)-1.43,-1.60,-1.77$.

${ }^{13} \mathrm{C}$ NMR (125.7 MHz, $\left.\mathrm{CD}_{3} \mathrm{CN}\right)$ 25.72, 27.93 (2 q, $\left.\mathrm{C}\left(\mathrm{CH}_{3}\right)_{2}\right)$, 55.44 (ribose-OMe), 69.91 [(P-coupled, $J=5.6), 70.17$ (P-coupled, $J$ $=5.8 \mathrm{~Hz}), 70.29(\mathrm{P}$-coupled $J=5.7), 5.37(\mathrm{P}$-coupled, $J=5.7 \mathrm{~Hz})$, 70.49 (P-coupled, $J=5.8 \mathrm{~Hz}, 2$ carbon signals), $(3 \times \mathrm{P}(\mathrm{O})$ $\left.\left(\mathrm{OCH}_{2} \mathrm{Ph}\right)_{2}\right)$ ], 71.90, 73.60, $73.80\left(\mathrm{t}, 2 \times \mathrm{CH}_{2} \mathrm{Ph}, \mathrm{CH}_{2} \mathrm{OBn}\right), 76.43$, 77.77, 78.25, 78.33 [(P-coupled, $J=4.6 \mathrm{~Hz}), 78.61$ (P-coupled, $J=$ $5.2 \mathrm{~Hz}$ ), 79.27 (P-coupled, $J=5.3 \mathrm{~Hz}), 80.98,81.07,81.82(\mathrm{P}$ coupled, $J=5.8,7.6 \mathrm{~Hz}$ ) ], 107.04 (P-coupled, $J=4.6 \mathrm{~Hz}$ ), 111.47 $\left(C_{\mathrm{q}}, \mathrm{C}(\mathrm{Me})_{2}\right), 128.46,128.48,128.51,128.52,128.84,129.01,129.03$, $129.15,129.20,129.25,129.30,129.39,129.42,129.45,129.47$, $129.49,129.52,129.56$ (d, $\left.C-\mathrm{H}, \mathrm{CH}_{2} P h\right), 137.02,137.04,137.07$, $137.09,137.13,137.26,137.33,137.48,137.54,139.13,139.53\left(C_{q}, \mathrm{~s}\right.$, $\left.\mathrm{CH}_{2} \mathrm{Ph}\right) . \mathrm{M} / z \mathrm{C}_{71} \mathrm{H}_{77} \mathrm{NaO}_{19} \mathrm{P}_{3}[\mathrm{M}+\mathrm{Na}]^{+}$expected 1349.4164; found 1349.4121. $[\alpha]_{2} 23^{\circ} \mathrm{C}=+20.7^{\circ},\left(c=1.9, \mathrm{CHCl}_{3}\right)$.

$(2 R, 3 S, 4 R, 5 S, 6 S)-3,4,6-$ Trihydroxy-5-(((3R,4R,5R)-2-(hydroxymethyl)-5-methoxy-4-(phosphonatooxy)tetrahydrofuran-3yl)oxy)cyclohexane-1,2-diyl bis(phosphate) (10) [D-chiro-Inositol Ribophostin (10)]. The phosphorylated compound (19, 90 $\mathrm{mg}, 67.8 \mu$ moles) was dissolved in $\mathrm{MeOH}(4 \mathrm{~mL})$, and water $(1 \mathrm{~mL})$ was added. Palladium hydroxide $(10,15 \mathrm{mg})$ was stirred vigorously in the presence of a balloon of hydrogen for $19.5 \mathrm{~h}$. About one-third (by volume) was removed and filtered, then two drops of triethylamine were added to form the salt and ${ }^{1} \mathrm{H}$ NMR was conducted. At this stage, the removal of the isopropylidene was incomplete (about a third was removed). One-third of the sample was evaporated to dryness and acidified using $80 \%$ acetic acid in $\mathrm{D}_{2} \mathrm{O}(5.0 \mathrm{~mL}$ in total), then stirred for $3 \mathrm{~h}$. The NMR results indicated that it was incomplete and was stirred in $80 \%$ acetic acid for a further $6 \mathrm{~h}$ and then for another $2 \mathrm{~h}$. The remaining compound was then left under stirring for about 1 week. After this time, methanol was removed and triethylamine was added. NMR results indicated that the isopropylidene group had been removed. The remaining compound was purified over Q-Sepharose ion-exchange resin using a gradient of $0-2$
M TEAB buffer. The compound eluted between 1.1 and $1.4 \mathrm{M}$ buffer and then on RP18 resin. Yield ( $28.9 \mu$ moles, $42.6 \%)$.

${ }^{1} \mathrm{H}$ NMR (400 MHz, MeOD) 3.41 (s, ribose-OMe), $3.63(1 \mathrm{H}, \mathrm{dd}$ $J=6 \mathrm{~Hz}, 12 \mathrm{~Hz}, \mathrm{H}-5 \mathrm{a}$-ribose $), 3.75(1 \mathrm{H}, \mathrm{dd}, J=3.6 \mathrm{~Hz}, 11.6 \mathrm{~Hz}, \mathrm{H}-$ 5b-ribose), $3.90(1 \mathrm{H}, \mathrm{dd}, J=3.2 \mathrm{~Hz}, 9.6 \mathrm{~Hz}, \mathrm{H}-5$-Ins), 3.98-4.05 (2 $\mathrm{H}, \mathrm{m}, \mathrm{H}$-2-Ins, H-4-ribose), $4.09(1 \mathrm{H}, \mathrm{t}, J=3.6 \mathrm{~Hz}, \mathrm{H}-1$ or H-6-Ins $)$, 4.17-4.20 (br m, H-3-ribose), $4.31(1 \mathrm{H}$, app q, $J=8.8 \mathrm{~Hz}, J=9.2$ Hz, H-3-Ins), $4.48(1 \mathrm{H}$, app q, $J=8.8 \mathrm{~Hz}, J=9.2 \mathrm{~Hz}, \mathrm{H}-4-\mathrm{Ins}), 4.65$ $(1 \mathrm{H}, \mathrm{dd}, J=4.4 \mathrm{~Hz}, \mathrm{H}$-2-ribose), 5.14 (s, H-1-ribose); $13 \mathrm{C}$ NMR (125.7 MHz, MeOD) 52.25 (ribose-OMe), $64.73\left(\mathrm{HOCH}_{2}\right.$-ribose), 70.68 (C-6-Ins), 72.10 (C-2-Ins), 72.85 (C-5-Ins), 77.36 (C-2ribose), 78.24 (C-4-Ins), 78.59 (C-3-Ins), 81.75 (C-3-Ribose), 82.37 (C-1-Ins), 83.13 (C-4-ribose), 108.69 (C-1-ribose); ${ }^{31} \mathrm{P}$ NMR (202 $\mathrm{MHz}, \mathrm{MeOD})+2.56,+1.93,+0.82 ; \mathrm{M} / z \mathrm{C}_{12} \mathrm{H}_{24} \mathrm{O}_{19} \mathrm{P}_{3}[\mathrm{M}-\mathrm{H}]^{-}$ expected 565.0130; found 565.0136.

D-3-O-1S-(-)-Camphanoyl-1,2:4,5-di-O-isopropylidenemyo-inositol (21). The upper diastereoisomer $(20,560.6 \mathrm{mg}, 1.0$ $\mathrm{mmol}$ ) and DDQ (454 mg, $2 \mathrm{mmol}$ ) in dichloromethane $0.5 \mathrm{M}$ phosphate buffer $\mathrm{pH} 7.4(20 \mathrm{~mL}, 19: 1)$ were stirred at room temperature overnight to give a deep green solution. The solution was diluted with dichloromethane $(100 \mathrm{~mL})$, and the pink-red precipitate that formed overnight was filtered off. The organic solution was then washed with a $10 \%$ solution of sodium hydrogen carbonate $(2 \times 100$ $\mathrm{mL})$ and water $(100 \mathrm{~mL})$. The organic layer was dried, filtered, and evaporated to give the crude product with $R_{\mathrm{f}}=0.24$ (ethyl acetate/ petroleum ether, $1: 1)$ and $R_{\mathrm{f}}$ of starting material $=0.54$. The crude product was purified by flash chromatography (ethyl acetate/ petroleum ether, 1:1 to ethyl acetate) to give the alcohol as a solid in $63 \%$ yield $(279 \mathrm{mg})$. The compound was recrystallized from $t$ butylmethyl ether-hexane. $[\alpha]_{\mathrm{D}}+24^{\circ}$ at temp $=22{ }^{\circ} \mathrm{C}, c=0.50$ $\left(\mathrm{CHCl}_{3}\right), \mathrm{mp}=223-226{ }^{\circ} \mathrm{C} .{ }^{1} \mathrm{H}$ NMR $\left(400 \mathrm{MHz}, \mathrm{CDCl}_{3}\right) 0.98(3$ $\mathrm{H}, \mathrm{s}, \mathrm{CH}_{3}$ - camphanate), 1.05 ( $3 \mathrm{H}, \mathrm{s}, \mathrm{CH}_{3}$ - camphanate), $1.11(3 \mathrm{H}$, $\mathrm{s}, \mathrm{CH}_{3^{-}}$, camphanate $), 1.28,1.43\left(6 \mathrm{H}, 2 \mathrm{~s}, \mathrm{C}-\left(\mathrm{CH}_{3}\right)_{2}\right.$, isopropylidene $), 1.45,1.49\left(6 \mathrm{H}, 2 \mathrm{~s}, \mathrm{C}-\left(\mathrm{CH}_{3}\right)_{2}\right.$, isopropylidene $)$, 1.65-1.72 (1 H, m, - $\mathrm{CH}$ - of - $\mathrm{CH}_{2}-$, camphanate $), 1.88-1.95(1 \mathrm{H}, \mathrm{m}$, $-\mathrm{CH}$ - of $-\mathrm{CH}_{2^{-}}$, camphanate), $2.04-2.10\left(1 \mathrm{H}, \mathrm{m},-\mathrm{CH}\right.$ - of $-\mathrm{CH}_{2}$, camphanate), 2.44-2.51 ( $1 \mathrm{H}, \mathrm{m},-\mathrm{CH}$ - of $-\mathrm{CH}_{2}-$, camphanate), 2.53 $\left(1 \mathrm{H}, \mathrm{d}, J=2.6 \mathrm{~Hz}, \mathrm{D}_{2} \mathrm{O}\right.$ exch. Ins- $\left.\mathrm{OH}\right), 3.40(1 \mathrm{H}, \mathrm{dd}, J=9.5,10.7$ $\mathrm{Hz}, \mathrm{H}-5), 3.88-3.93\left(1 \mathrm{H}, \mathrm{br}\right.$ ddd, $2.3,6.5,9.1 \mathrm{~Hz}, \mathrm{D}_{2} \mathrm{O}$ exch. $J=6.5$, $10.7 \mathrm{~Hz}, \mathrm{H}-6), 4.05(1 \mathrm{H}, \mathrm{dd}, J=9.5 \mathrm{~Hz}, 10.4 \mathrm{~Hz}, \mathrm{H}-4), 4.08(1 \mathrm{H}, \mathrm{t}$, $J=5.8 \mathrm{~Hz}, \mathrm{H}-1), 4.63(1 \mathrm{H}, \mathrm{t}, J=4.8 \mathrm{~Hz}, \mathrm{H}-2), 5.20(1 \mathrm{H}, \mathrm{dd}, J=4.4$, $10.5 \mathrm{~Hz}, \mathrm{H}-3)$.

${ }^{13} \mathrm{C}$ NMR (100 MHz, $\left.\mathrm{CDCl}_{3}\right)$ 9.74, 16.49, 16.65 (3 q, $-\mathrm{CH}_{3}$, camphanate), 25.74, 26.85, 26.94, $28.10\left(4 \mathrm{q}, 2 \times \mathrm{C}\left(\mathrm{CH}_{3}\right)_{2}\right), 28.98$, $30.58\left(2 \mathrm{t}, 2 \times-\mathrm{CH}_{2}\right.$-, camphanate), 54.71, $54.90\left(2 \mathrm{~s}, \mathrm{C}_{\mathrm{q}}\right.$, camphanate), 72.10, 74.43, 74.49, 74.63, 78.14, 81.90 (6 d, $6 \times$ inositol ring carbons), $91.02\left(\mathrm{~s}, C_{q}\right.$, camphanate), 110.33, 112.99 ( $2 \mathrm{~s}$, $\left.\mathrm{C}_{\mathrm{q}}, \mathrm{C}\left(\mathrm{CH}_{3}\right)_{2}\right), 167.14\left(\mathrm{~s}, \mathrm{C}_{\mathrm{q}},(\mathrm{O}-\mathrm{C}=\mathrm{O})\right.$, camphanate $), 178.11\left(\mathrm{~s}, \mathrm{C}_{\mathrm{q}}\right.$, $\mathrm{C}=\mathrm{O}$, camphanate). $\mathrm{C}_{22} \mathrm{H}_{32} \mathrm{O}_{9}$, Expected: $\mathrm{C}=59.99, \mathrm{H}=7.32$; Found: $\mathrm{C}=60.0, \mathrm{H}=7.42 . M / z \mathrm{C}_{22} \mathrm{H}_{32} \mathrm{NaO}_{9}$, Expected: 463.1939; Found 463.1950.

D-(-)-1,2:4,5-Di-O-isopropylidene-myo-inositol (22). A mixture of D-3-O-1S-(-)-Camphanoyl-1,2:4,5-di-O-isopropylidene-myoinositol $(21,237 \mathrm{mg}, 0.538 \mathrm{mmol})$ and $\mathrm{MeOH}(50 \mathrm{~mL})$ was heated under reflux in the presence of $\mathrm{NaOH}(73 \mathrm{mg}, 1.82 \mathrm{mmol})$ for 30 min. The solvent was further diluted with $\mathrm{MeOH}(50 \mathrm{~mL})$, and the solution was neutralized by bubbling carbon dioxide through it. Water $(10 \mathrm{~mL})$ was added, and the solvents were evaporated off to give a solid. Extraction of the product $\left(\mathrm{CH}_{2} \mathrm{Cl}_{2}\right)$ gave the $\left(\mathrm{EtOAc}-\mathrm{CH}_{2} \mathrm{Cl}_{2}\right.$, $\left.R_{\mathrm{f}}=0.20\right)$ purified product as a white solid $(115 \mathrm{mg}, 82 \%)$ from EtOAc. $[\alpha]_{\mathrm{D}}=-23^{\circ}$, temperature $=21^{\circ} \mathrm{C}, c=0.50$ in $\mathrm{CH}_{3} \mathrm{CN}$, Lit. + $22^{\circ}(c=1.08, \mathrm{MeCN})^{36}$ (for opposite enantiomer). Lit. $-22^{\circ}(c=1$, $\mathrm{MeCN})^{37}$ Lit. $-21.7^{\circ}(c=0.46, \mathrm{MeCN}) ;^{38} \mathrm{mp} 157-159{ }^{\circ} \mathrm{C}$; Lit. ${ }^{36}$ $\mathrm{mp}=159-161{ }^{\circ} \mathrm{C}$.

${ }^{1} \mathrm{H}$ NMR (400 MHz, $\left.\mathrm{CDCl}_{3}\right)$ 1.36, 1.44, 1.47, $1.52(12 \mathrm{H}, 2 \times$ $\mathrm{C}\left(\mathrm{CH}_{3}\right)_{2}$, isopropylidene), $2.56\left(1 \mathrm{H}, \mathrm{d}, J=8.6 \mathrm{~Hz}\right.$, Ins-3-OH, $\mathrm{D}_{2} \mathrm{O}$, exch.), $2.80\left(1 \mathrm{H}, \mathrm{d}, J=3.0 \mathrm{~Hz}\right.$, Ins-6-OH, $\mathrm{D}_{2} \mathrm{O}$, exch. $), 3.31(1 \mathrm{H}$, dd, $J=9.4,10.7 \mathrm{~Hz}, \mathrm{H}-5), 3.82(1 \mathrm{H}, \mathrm{t}, J=9.6 \mathrm{~Hz}, \mathrm{H}-4), 3.88(1 \mathrm{H}, \mathrm{ddd}, J$ $=3.0,6.5,10.7 \mathrm{~Hz}, \mathrm{D}_{2} \mathrm{O}$ exch. dd, $\left.J=6.4,10.7 \mathrm{~Hz}, \mathrm{H}-6\right), 4.02(1 \mathrm{H}$, 
ddd, 4.5, 8.6, $10.6 \mathrm{~Hz}, \mathrm{D}_{2} \mathrm{O}$ exch. dd, $J=4.5,10.1 \mathrm{~Hz}, \mathrm{H}-3$ ), 4.06 (1 $\mathrm{H}, \mathrm{dd}, J=5.8,6.4 \mathrm{~Hz}, \mathrm{H}-1), 4.46(1 \mathrm{H}, \mathrm{t}, J=4.8 \mathrm{~Hz}, \mathrm{H}-2)$.

${ }^{13} \mathrm{C}$ NMR $\left(100 \mathrm{MHz}, \mathrm{CDCl}_{3}\right) 25.86,26.89,26.90,28.08$ (4 q, $2 \times$ $\mathrm{C}\left(\mathrm{CH}_{3}\right)_{2}$, isopropylidene), 69.80, 74.82, 77.59, 77.98, 78.03, 81.84 (6 d, inositol ring carbons), $110.29,112,72\left(2 \mathrm{~s}, \mathrm{C}_{\mathrm{q}}, 2 \times \mathrm{C}\left(\mathrm{CH}_{3}\right)_{2}\right.$, isopropylidene).

\section{ASSOCIATED CONTENT}

\section{SI Supporting Information}

The Supporting Information is available free of charge at https://pubs.acs.org/doi/10.1021/acs.jmedchem.9b01986.

Spectral data including ${ }^{1} \mathrm{H}$ NMR, ${ }^{31} \mathrm{P} \mathrm{NMR}$, and ${ }^{13} \mathrm{C}$ NMR for compounds, including final compound (PDF) Molecular formula strings (CSV)

\section{AUTHOR INFORMATION}

\section{Corresponding Author}

Barry V. L. Potter - Drug Discovery \& Medicinal Chemistry, Department of Pharmacology, University of Oxford, Oxford OX1 3QT, United Kingdom; o orcid.org/0000-0003-32559135; Email: barry.potter@pharm.ox.ac.uk

\section{Authors}

Stephen J. Mills - Drug Discovery \& Medicinal Chemistry, Department of Pharmacology, University of Oxford, Oxford OX1 3QT, United Kingdom

Ana M. Rossi - Department of Pharmacology, University of Cambridge, Cambridge CB2 1PD, United Kingdom

Vera Konieczny - Department of Pharmacology, University of Cambridge, Cambridge CB2 1PD, United Kingdom

Daniel Bakowski - Centre of Integrative Physiology, Department of Physiology, Anatomy and Genetics, University of Oxford, Oxford OX1 3PT, United Kingdom

Colin W. Taylor - Department of Pharmacology, University of Cambridge, Cambridge CB2 1PD, United Kingdom

Complete contact information is available at: https://pubs.acs.org/10.1021/acs.jmedchem.9b01986

\section{Author Contributions}

The manuscript was written by S.J.M. and B.V.L.P. with contributions from all authors, who approved the final version.

\section{Notes}

The authors declare no competing financial interest.

\section{ACKNOWLEDGMENTS}

This work was supported by the Wellcome Trust. B.V.L.P. and C.W.T. are Wellcome Trust Senior Investigators (grant Nos. 101010 and 101844, respectively). A.M.R. is a Fellow at Queens' College, Cambridge. The authors thank Drs. Xiangdong $\mathrm{Su}$ and Wolfgang Dohle for a sample of authentic 4 and Dr A. M. Riley for useful discussions during this work.

\section{ABBREVIATIONS}

DDQ 2,3-dichloro-5,6-dicyano-1,4-benzoquinone; HMPA, hexamethyl-phosphoramide; $\operatorname{Ins}(1,4,5) \mathrm{P}_{3}$, D-myo-inositol trisphosphate; Ins $(1,4,5) \mathrm{P}_{3} \mathrm{R}, \mathrm{D}-m y o$-inositol trisphosphate receptor; THF, tetrahydrofuran; HEK, human embryonic kidney; SEM, standard error of mean; IBC, inositol binding core; RBL, rat basophilic leukemic; TEAB, triethylammonium bicarbonate

\section{REFERENCES}

(1) Bosanac, I.; Alattia, J.-R.; Mal, T. K.; Chan, J.; Talarico, S.; Tong, F. K.; Tong, K. I.; Yoshikawa, F.; Furuichi, T.; Iwai, M.; Michikawa, T.; Mikoshiba, K.; Ikura, M. Structure of the inositol 1,4,5trisphosphate receptor binding core in complex with its ligand. Nature 2002, 420, 696-700.

(2) Fan, G.; Baker, M. R.; Wang, Z.; Seryshev, A. B.; Ludtke, S. J.; Baker, M. L.; Serysheva, I. I. Cryo-EM reveals ligand induced allostery underlying $\mathrm{InsP}_{3} \mathrm{R}$ channel gating. Cell Res. 2018, 28, 1158-1170.

(3) Paknejad, N.; Hite, R. K. Structural basis for the regulation of inositol trisphosphate receptors by $\mathrm{Ca}^{2+}$ and $\mathrm{IP}_{3}$. Nat. Struct. Mol. Biol. 2018, 25, 660-668.

(4) Rossi, A. M.; Taylor, C. W. $\mathrm{IP}_{3}$ receptors-lessons from analyses ex cellula. J. Cell. Sci. 2019, 132, No. jcs222463.

(5) Potter, B. V. L.; Lampe, D. Chemistry of inositol lipid mediated cellular signaling. Angew. Chem., Int. Ed. 1995, 34, 1933-1972.

(6) Swarbrick, J. M.; Riley, A. M.; Mills, S. J.; Potter, B. V. L. Designer small molecules to target calcium signalling. Biochem. Soc. Trans. 2015, 43, 417-425.

(7) Thomas, M. P.; Mills, S. J.; Potter, B. V. L. The "other" inositols and their phosphates: synthesis, biology and medicine (with recent advances in myo-inositol chemistry). Angew. Chem., Int. Ed. 2016, 55, $1614-1650$.

(8) Takahashi, M.; Kagasaki, T.; Hosoya, T.; Takahashi, S. Adenophostins A and B: potent agonists of inositol-1,4,5-trisphosphate receptor produced by Penicillium brevicompactum. J. Antibiot. 1993, 46, 1643-1647.

(9) Takahashi, M.; Tanzawa, K.; Takahashi, S. Adenophostins, newly discovered metabolites of Penicillium brevicompactum, act as potent agonists of the inositol 1,4,5-trisphosphate receptor. J. Biol. Chem. 1994, 269, 369-372.

(10) Takahashi, S.; Kinoshita, T.; Takahashi, M. Adenophostins A and B: potent agonists of the inositol-1,4,5-trisphosphate receptor produced by Penicillium brevicompactum. structure elucidation. J. Antibiot. 1994, 47, 95-100.

(11) Saleem, H.; Tovey, S. C.; Riley, A. M.; Potter, B. V. L.; Taylor, C. W. Stimulation of inositol 1,4,5-trisphosphate $\left(\mathrm{IP}_{3}\right)$ receptor subtypes by adenophostin A and its analogues. PLoS One 2013, 8, No. e58027.

(12) Rossi, A. M.; Sureshan, K. M.; Riley, A. M.; Potter, B. V. L.; Taylor, C. W. Selective determinants of inositol 1,4,5-trisphosphate and adenophostin A interactions with type 1 inositol 1,4,5trisphosphate receptors. Br. J. Pharmacol. 2010, 161, 1070-1085.

(13) Sureshan, K. M.; Riley, A. M.; Thomas, M. P.; Tovey, S. C.; Taylor, C. W.; Potter, B. V. L. Contribution of phosphates and adenine to the potency of adenophostins at the $\mathrm{IP}_{3}$ receptor: synthesis of all possible bisphosphates of adenophostin A. J. Med. Chem. 2012, $55,1706-2120$.

(14) Mochizuki, T.; Kondo, Y.; Abe, H.; Tovey, S. C.; Dedos, S. G.; Taylor, C. W.; Paul, M.; Potter, B. V. L.; Matsuda, A.; Shuto, S. Synthesis of adenophostin A analogues conjugating an aromatic group at the $5^{\prime}$-position as potent $\mathrm{IP}_{3}$ receptor ligands. J. Med. Chem. 2006, $49,5750-5758$.

(15) Mochizuki, T.; Tanimura, A.; Nezu, A.; Ito, M.; Abe, H.; Ito, Y.; Arisawa, M.; Shuto, S. Design and synthesis of indole derivatives of adenophostin A. A entry into subtype-selective $\mathrm{IP}_{3}$ receptor ligands. Tetrahedron Lett. 2010, 51, 977-979.

(16) Vibhute, A. M.; Konieczny, V.; Taylor, C. W.; Sureshan, K. M. Triazolophostins: a library of novel and potent agonists of $\mathrm{IP}_{3}$ receptors. Org. Biomol. Chem. 2015, 13, 6698-6910.

(17) Vibhute, A. M.; Pushpanandan, P.; Varghese, M.; Koniecnzy, V.; Taylor, C. W.; Sureshan, K. M. Synthesis of dimeric analogs of adenophostin $\mathrm{A}$ that potently evoke $\mathrm{Ca}^{2+}$ release through $\mathrm{IP}_{3}$ receptors. RSC Adv. 2016, 6, 86346-86351.

(18) Rossi, A. M.; Riley, A. M.; Potter, B. V. L.; Taylor, C. W. Adenophostins: high-affinity agonists of $\mathrm{IP}_{3}$ receptors. Curr. Top. Membr. 2010, 66, 209-233.

(19) Correa, V. A.; Riley, A. M.; Shuto, S.; Horne, G.; Nerou, E. P.; Marwood, R. D.; Potter, B. V. L.; Taylor, C. W. Structural 
determinants of adenophostin A activity at inositol trisphosphate receptors. Mol. Pharmacol. 2001, 59, 1206-1215.

(20) Dohle, W.; Su, X.; Mills, S. J.; Rossi, A. M.; Taylor, C. W.; Potter, B. V. L. A synthetic cyclitol-nucleoside conjugate polyphosphate is a highly potent second messenger mimic. Chem. Sci. 2019, 10, 5382-5390.

(21) Rosenberg, H. J. A.; Riley, A. M.; Laude, A. J.; Taylor, C. W.; Potter, B. V. L. Synthesis and $\mathrm{Ca}^{2+}$ mobilising activity of purinemodified mimics of adenophostin A: a model for the adenophostinIns $(1,4,5) \mathrm{P}_{3}$ receptor interaction. J. Med. Chem. 2003, 46, 48604871 .

(22) Sureshan, K. M.; Riley, A. M.; Rossi, A. M.; Tovey, S. C.; Dedos, S. G.; Taylor, C. W.; Potter, B. V. L. Activation of $\mathrm{IP}_{3}$ receptors by synthetic bisphosphate ligands. Chem. Commun. 2009, 45, 1204-1206.

(23) Nerou, E. P.; Riley, A. M.; Potter, B. V. L.; Taylor, C. W. Selective recognition of inositol phosphates by subtypes of the inositol trisphosphate receptor. Biochem. J. 2001, 355, 59-69.

(24) Chrètien, F.; Moitessier, N.; Roussel, F.; Mauger, J.-P.; Chapleur, Y. Carbohydrate based mimics of D-myo-inositol 1,4,5trisphosphate. Curr. Org. Chem. 2000, 4, 513-534.

(25) Hotoda, H.; Murayama, K.; Miyamoto, S.; Iwata, Y.; Takahashi, M.; Kawase, Y.; Tanzawa, K.; Kaneko, M. Adenophostin, a very potent $\mathrm{Ca}^{2+}$ inducer at the $\mathrm{d}$-myo-inositol 1,4,5-trisphosphate receptor. Biochemistry 1999, 38, 9234-9241.

(26) Safrany, S. T.; Wojcikiewicz, R. J. H.; Strupish, J.; Nahorski, S. R.; Dubreuil, D.; Chleophax, J.; Gero, S. D.; Potter, B. V. L. Interaction of synthetic D-6-deoxy-myo-inositol 1,4,5-trisphosphate with the $\mathrm{Ca}^{2+}$-releasing D-myo-1,4,5-trisphosphate receptor and the metabolic enzymes 5-phosphatase and 3-kinase. FEBS Lett. 1991, 278, $252-256$.

(27) Jenkins, D. J.; Potter, B. V. L. (2-Hydroxyethyl)- $\alpha$-dglucopyranoside 2',3,4-trisphosphate: synthesis of a second messenger mimic related to adenophostin A. J. Chem. Soc., Chem. Commun. 1995, $1169-1170$.

(28) Jenkins, D. J.; Potter, B. V. L. A Ca ${ }^{2+}$ mobilising carbohydratebased polyphosphate: synthesis of 2-hydroxyethyl- $\alpha$-D-glucopyranoside 2',3,4-trisphosphate. Carbohydr. Res. 1996, 287, 169-182.

(29) Wilcox, R. A.; Erneux, C.; Primrose, W. U.; Gigg, R.; Nahorski, S. R. 2-Hydroxyethyl $\alpha$-D-glucopyranoside 2,3',4'-trisphosphate: a novel metabolically resistant adenophostin $\mathrm{A}$ and myo-inositol 1,4,5trisphosphate analogue potently interacts with the myo-inositol 1,4,5trisphosphate receptor. Biochem. Soc. Trans. 1995, 23, 420 S.

(30) Rosenberg, H. J.; Riley, A. M.; Marwood, R. D.; Correa, V.; Taylor, C. W.; Potter, B. V. L. Xylopyranoside-based agonists of Dmyo-inositol 1,4,5-trisphosphate receptors: synthesis and effect of stereochemistry on biological activity. Carbohydr. Res. 2001, 332, 5356.

(31) Jenkins, D. J.; Marwood, R. D.; Potter, B. V. L. A disaccharide polyphosphate mimic of 1D-myo-inositol 1,4,5-trisphosphate. Chem. Commun. 1997, 449-450.

(32) Mills, S. J.; Potter, B. V. L. Synthesis of D- and L-myo-inositol 1,4,6-trisphosphate, regioisomers of a ubiquitous second messenger. J. Org. Chem. 1996, 61, 8980-8987.

(33) Hamblin, M. R.; Potter, B. V. L.; Gigg, R. Bis-phosphorylation of a vic-diol: synthesis of myo-inositol 4,5-bisphosphate. J. Chem. Soc., Chem. Commun. 1987, 626-627.

(34) Briggs, A. J. A modification of the Bell-Doisy phosphate method. J. Biol. Chem. 1922, 53, 13-16.

(35) Lampe, D.; Liu, C.; Potter, B. V. L. Synthesis of selective non$\mathrm{Ca}^{2+}$ mobilizing inhibitors of D-myo-inositol 1,4,5-trisphosphate 5phosphatase. J. Med. Chem. 1994, 37, 907-912.

(36) Jones, M.; Rana, K. K.; Ward, J. G.; Young, R. C. Improved synthesis of inositol phospholipid analogues. Tetrahedron Lett. 1989, 30, 5353-5356.

(37) Mills, S. J.; Potter, B. V. L. Synthesis of the enantiomers of myoinositol 1,2,4,5-tetrakisphosphate, a regioisomer of myo-inositol 1,3,4,5-tetrakisphosphate. J. Chem. Soc., Perkin Trans. 1 1997, $1279-1286$.
(38) Chiara, J. L.; Martín-Lomas, M. A Stereoselective route to enantiomerically pure myo-inositol derivatives starting from Dmannitol. Tetrahedron Lett. 1994, 35, 2969-2972.

(39) Rossi, A. M.; Riley, A. M.; Tovey, S. C.; Rahman, T.; Dellis, O.; Taylor, E. J.; Veresov, V. G.; Potter, B. V. L.; Taylor, C. W. Synthetic partial agonists reveal key steps in $\mathrm{IP}_{3}$ receptor activation. Nat. Chem. Biol. 2009, 5, 631-639.

(40) Marchant, J. S.; Beecroft, M. D.; Riley, A. M.; Jenkins, D. J.; Marwood, R. D.; Taylor, C. W.; Potter, B. V. L. Disaccharide polyphosphates based upon adenophostin A activate hepatic D-myoinositol 1,4,5-trisphosphate receptors. Biochemistry 1997, 36, 1278012790.

(41) Shuto, S.; Horne, G.; Marwood, R. D.; Potter, B. V. L. Total synthesis of nucleobase-modified adenophostin A mimics. Chem. Eur. J. 2001, 7, 4937-4946.

(42) Beecroft, M. D.; Marchant, J. S.; Riley, A. M.; van Straten, N. C. R.; Van der Marel, G. A.; van Boom, J. H.; Potter, B. V. L.; Taylor, C. W. Acyclophostin: a ribose-modified analog of adenophostin A with high affinity for inositol 1,4,5-trisphosphate receptors and $\mathrm{pH}$ dependent efficacy. Mol. Pharmacol. 1999, 55, 109-117.

(43) Roussel, F.; Hilly, M.; Chrétien, F.; Manger, J.-P.; Chapleur, Y. Synthesis and biological evaluation of (2-hydroxyethyl)-2-deoxy- $\alpha$-Dthreo-pyranoside 3,4,2'-trisphosphate, a mimic of the second messenger inositol 1,4,5-trisphosphate. J. Carbohydr. Chem. 1999, $18,697-707$

(44) Saleem, H.; Tovey, S. C.; Rahman, T.; Riley, A. M.; Potter, B. V. L.; Taylor, C. W. Stimulation of inositol 1,4,5-trisphosphate $\left(\mathrm{IP}_{3}\right)$ receptor subtypes by analogues of $\mathrm{IP}_{3}$. PLoS One 2013, 8, No. e54877.

(45) Riley, A. M.; Correa, V.; Mahon, M. F.; Taylor, C. W.; Potter, B. V. L. Bicyclic analogs of D-myo-inositol 1,4,5-trisphosphate related to adenophostin A: synthesis and biological activity. J. Med. Chem. 2001, 44, 2108-2117.

(46) de Kort, M.; Regenbogen, A. D.; Valentijn, R. A. P. M.; Challiss, R. A. J.; Iwata, Y.; Miyamoto, S.; van der Marel, G. A.; van Boom, J. H. Spirophostins: conformationally restricted analogues of adenophostin A. Chem. - Eur. J. 2000, 6, 2696-2704.

(47) Parekh, A. B.; Fleig, A.; Penner, R. The store-operated calcium current $\mathrm{I}(\mathrm{CRAC})$ : nonlinear activation by $\mathrm{InsP}_{3}$ and dissociation from calcium release. Cell 1997, 89, 973-980.

(48) Parekh, A. B.; Riley, A. M.; Potter, B. V. L. Adenophostin A and ribophostin, but not inositol 1,4,5-trisphosphate or manno-adenophostin, activate the $\mathrm{Ca}^{2+}$ release-activated $\mathrm{Ca}^{2+}$ current, $I_{\mathrm{CRAC}}$, in weak intracellular $\mathrm{Ca}^{2+}$ buffer. Biochem. J. 2002, 361, 133-141. 